\title{
Antitumour potential of BPT: a dual inhibitor of cdk4 and tubulin polymerization
}

\author{
S Mahale ${ }^{1}$, SB Bharate ${ }^{\star 2,3}$, S Manda ${ }^{2,3}$, P Joshi ${ }^{2,3}$, PR Jenkins ${ }^{4}$, RA Vishwakarma ${ }^{2,3}$ and B Chaudhuri ${ }^{*, 1}$
}

The marine natural product fascaplysin (1) is a potent Cdk4 (cyclin-dependent kinase 4)-specific inhibitor, but is toxic to all cell types possibly because of its DNA-intercalating properties. Through the design and synthesis of numerous fascaplysin analogues, we intended to identify inhibitors of cancer cell growth with good therapeutic window with respect to normal cells. Among various non-planar tryptoline analogues prepared, $N$-(biphenyl-2-yl) tryptoline (BPT, 6) was identified as a potent inhibitor of cancer cell growth and free from DNA-binding properties owing to its non-planar structure. This compound was tested in over 60 protein kinase assays. It displayed inhibition of Cdk4-cyclin D1 enzyme in vitro far more potently than many other kinases including Cdk family members. Although it blocks growth of cancer cells deficient in the mitotic-spindle checkpoint at the $G_{0} / G_{1}$ phase of the cell cycle, the block occurs primarily at the $G_{2} / M$ phase. BPT inhibits tubulin polymerization in vitro and acts as an enhancer of tubulin depolymerization of paclitaxel-stabilized tubulin in live cells. Western blot analyses indicated that, in p53-positive cells, BPT upregulates the expression of p53, p21 and p27 proteins, whereas it downregulates the expression of cyclin B1 and Cdk1. BPT selectively kills SV40-transformed mouse embryonic hepatic cells and human fibroblasts rather than untransformed cells. BPT inhibited the growth of several human cancer cells with an $\mathrm{IC}_{50}<1 \mu \mathrm{M}$. The pharmacokinetic study in BALB/c mice indicated good plasma exposure after intravenous administration. It was found to be efficacious at $1 / 10$ th the maximum-tolerated dose $(1000 \mathrm{mg} / \mathrm{kg}$ ) against human tumours derived from HCT-116 (colon) and NCl-H460 (lung) cells in SCID (severe-combined immunodeficient) mice models. BPT is a relatively better anticancer agent than fascaplysin with an unusual ability to block two overlapping yet crucial phases of the cell cycle, mitosis and $\mathrm{G}_{0} / \mathrm{G}_{1}$. Its ability to effectively halt tumour growth in human tumourbearing mice would suggest that BPT has the potential to be a candidate for further clinical development.

Cell Death and Disease (2015) 6, e1743; doi:10.1038/cddis.2015.96; published online 7 May 2015

A link between development of human cancers and cellular pathways where the retinoblastoma protein $(\mathrm{pRb})$ has a major role is well established. ${ }^{1,2}$ One of the frequent events associated with human tumour progression is abnormality in the pathway that links pRb, p16 ${ }^{\mathrm{INK} 4 \mathrm{~A}}$, cyclin D1 and Cdk4 (cyclin-dependent kinase 4). ${ }^{3}$ Cdk4 along with its activating cyclin partner D1 has a key role in cell cycle control. ${ }^{4,5}$ The naturally occurring inhibitor of Cdk4-cyclin D1, p16 ${ }^{\text {INK4a }}$ (p16), is a tumour supressor protein. Deletion or inactivating mutations in the p16 gene are observed in many human cancers. ${ }^{6,7}$ The catalytic activity of Cdk4 depends on its activation by the protein cyclin $\mathrm{D} 1$, which is expressed during the $G_{0} / G_{1}$ phase of the cell cycle. Many cancers are characterised by abnormal overproduction of cyclin D1. ${ }^{8,9}$ As Cdk4 inhibitors target a pathway that links pRb, p16INK4A, cyclin D1 and Cdk4, it makes inhibition of Cdk4-cyclin D1 enzyme a crucially important target for cancer chemotherapy. ${ }^{10-13}$ However, Rb mutations, consistent with loss of $\mathrm{Rb}$ function, have been identified in a wide spectrum of tumours including osteosarcomas, small-cell lung carcinomas, breast carcinomas and others, and the Cdk4 inhibitors cannot inhibit such pathway involving Rb-mutated tumours.

A number of potential anticancer agents that selectively modulate the activity of Cdk4-cyclin D1 in vitro have been reported. ${ }^{14}$ These molecules also show the genotypic consequences of Cdk4 enzyme inhibition at the cellular level, that is, growth inhibition of cancer cells in vitro, arrest of asynchronous cells at $G_{0} / G_{1}$ and prevention of $p R b$ phosphorylation at $C d k 4$-specific serine residues. ${ }^{15-17}$ Usually, competing with ATP molecules for binding at the protein kinase active site is the normal mechanism by which most small molecules inhibit kinase enzyme activity. Successful attempts to identify selective Cdk4 inhibitors using structure-based chemical design and molecular modelling have been reported. ${ }^{18-20}$ Furthermore, the success of Cdk4 inhibitors at clinical

\section{IIIM Publication Number: IIIM/782/2015.}

${ }^{1}$ School of Pharmacy, De Montfort University, Leicester LE1 9BH, UK; ${ }^{2}$ Medicinal Chemistry Division, CSIR-Indian Institute of Integrative Medicine, Canal Road, Jammu 180001, India; ${ }^{3}$ Academy of Scientific and Innovative Research (AcSIR), CSIR-Indian Institute of Integrative Medicine, Canal Road, Jammu 180001, India and ${ }^{4}$ Department of Chemistry, University of Leicester, Leicester LE1 7RH, UK

*Corresponding author: B Chaudhuri, School of Pharmacy, De Montfort University, Leicester LE1 9BH, UK. Tel: +44 (0)116 250 7280; Fax: +44 (0)116 257 7287 ; E-mail: bchaudhuri@dmu.ac.uk

or SB Bharate, Medicinal Chemistry Division, CSIR-Indian Institute of Integrative Medicine, Canal Road, Jammu-180001, India. Tel: +91 1912585006 (Extn. 345$)$; Fax: +91 191 2586333; E-mail: sbharate@iiim.ac.in

Abbreviations: Cdk, cyclin-dependent kinase; d/w, distilled water; d-s, double-stranded; EtBr, ethidium bromide; mpk, milligrams per kilogram of body weight; MTD, maximum-tolerated dose; NSCLC, non-small-cell lung cancer; pRb, retinoblastoma protein; r.p.m., revolutions per minute; SCID, severe combined immunodeficient Received 28.11.14; revised 26.2.15; accepted 02.3.15; Edited by A Oberst 
stages $^{21-25}$ has indicated it as a promising therapeutic target for anticancer drug discovery. ${ }^{14}$

Fascaplysin (1), a natural product originally isolated from a marine sponge, specifically inhibits the Cdk4 enzyme. ${ }^{26,27}$ It inhibits Cdk4-cyclin D1 with an $\mathrm{IC}_{50}$ of $\sim 0.35 \mu \mathrm{M}$ and blocks growth of cancer cells at the $\mathrm{G}_{0} / \mathrm{G}_{1}$ phase of the cell cycle. Similar to cryptolepine and ellipticine ${ }^{28}$ fascaplysin is also a planar structure and thus it intercalates double-stranded (d-s) DNA and shows unusual toxicity at the cellular level. It has been suggested that fascaplysin's planar structure is the possible explanation for its ability to intercalate d-s DNA and also its unusual toxicity at the cellular level. To overcome this unusual toxicity, recently we reported CA224 (2), a non-planar analogue of fascaplysin exhibiting selective Cdk4 inhibition with no DNA-intercalating property. ${ }^{29}$ In continuation to these efforts, herein we report identification of tryptoline-based compounds CA198 (3), CA199 (4), CA211 (5) and $\mathrm{N}$-(biphenyl-2-yl)-tryptoline (BPT, 6) as selective Cdk4 inhibitors with no DNA-intercalating property. Based on the molecular modelling design, a number of non-planar analogues of fascaplysin were synthesized. They show specificity towards Cdk4-cyclin D1 enzyme activity and blocks the growth of cancer cells at the $\mathrm{G}_{0} / \mathrm{G}_{1}$ phase. Although BPT was also designed using a homology model of Cdk4, based on the X-ray crystallographic structures of Cdk2, Cdk4 and Cdk6, ${ }^{30-33}$ further investigations showed that BPT blocks growth of cells at the $\mathrm{G}_{2} / \mathrm{M}$ phase, in a Cdk-independent manner, through inhibition of tubulin polymerization. BPT shows potent cytotoxicity in a panel of cancer cells and is efficacious against human tumours derived from HCT-116 and $\mathrm{NCl}-\mathrm{H} 460$ cells in SCID mice models. Here, we present the biological activity of BPT in detail. BPT (6) was synthesized using a one-step procedure by coupling tryptoline with biphenyl 2-carboxylic acid. The chemical synthesis of BPT and chemical structures of 1-6 are shown in Figure 1.

\section{Results}

Selective inhibition of Cdk4-cyclin D1 by BPT. BPT inhibits Cdk4-cyclin D1 in vitro at low micromolar concentration $\left(\mathrm{IC}_{50}=10 \mu \mathrm{M}\right)$ and is comparatively inactive against other members of Cdk family. BPT was tested against a panel of 58 representative kinases including Cdk5-p35, Cdk6-cyclin D1, Cdk7-cyclin H, EGFR, GSK3 $\beta$, MAPK1, MEK1, PDGFR, PIk3, PKA, PKCa, IGF-1R, and so on, wherein it does not inhibit any kinase to any appreciable degree at $10 \mu \mathrm{M}$ (Table 1).

To understand the observed selectivity towards Cdk4-cyclin D1 versus Cdk2-cyclin A, molecular modelling studies were performed. ${ }^{33}$ These two Cdks share $45 \%$ sequence homology; however, they differ by three peptidic sequences

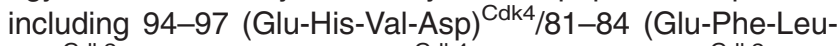
His) ${ }^{\mathrm{Cdk} 2}$, 101-102 (Arg-Thr) ${ }^{\mathrm{Cdk} 4} / 88-89$ (Lys-Lys) ${ }^{\mathrm{Cdk} 2}$ and Glu144 ${ }^{\text {Cdk4 }} /$ Gln $131^{\text {Cdk2 }}$. BPT interacts with ATP-binding pocket of Cdk4-cyclin D1 with 83-fold selectivity with respect to Cdk2-cyclin A because of flexible conformational movement of the BPT amide bond, which allows free rotation of biphenyl ring leading to subsequent gain or loss of major hydrophobic interactions with one or other Cdk. BPT interacts with these
Cdks in two different conformational states: (a) in cis conformation (green-coloured ligand in Figure 1c, $\psi=-9.6$ ), it interacts selectively with the side chain of Arg101 residue of Cdk4-cyclin D1 by hydrophobic $\pi$-cation interaction, whereas in Cdk2-cyclin A, this interaction is missing as the corresponding Lys88 residue side chain orients away from BPT-binding cavity, and (b) in trans conformation (orange-coloured ligand in Figure 1c; $\psi=161.1$ ), it interacts with Cdk2-cyclin A.

DNA-binding assay. The ability of BPT to intercalate d-s DNA was important to segregate it from fascaplysin. It was studied by ethidium bromide (EtBr) dispacement assay and topoisomerase-I catalysed DNA relaxation or unwinding assay in vitro. Unlike fascaplysin, BPT failed to displace bound EtBr from DNA, indicating that it does not compete with EtBr-binding sites on DNA (EtBr is known to bind to the minor groove of d-s DNA, and also to DNA double helix and crosslinking sites ${ }^{34}$ ) and therefore shows no detectable affinity towards DNA (Table 1 and Supplementary Figure $\mathrm{S} 5 \mathrm{C})$. The interactions of fascaplysin, actinomycin D and BPT with pBluescript plasmid DNA is depicted in Supplementary Figure S5C. As indicated in Supplementary Figures S5A and $\mathrm{C}, 100 \mu \mathrm{M}$ of BPT was incapable of displacing $1.3 \mu \mathrm{M}$ of EtBr from pBluescript plasmid DNA. In contrast, DNA-intercalating agents actinomycin D and fascaplysin readily dislodges the bound EtBr. Usually, DNA intercalators hinder topoisomerase-catalysed DNA relaxation/unwinding process. Fascaplysin at low dose also hinder topoisomerase-I catalysed DNA relaxation, whereas BPT at much higher concentration than fascaplysin does not hinder DNA relaxation process, as indicated by two different bands on agarose gel (Supplementary Figure S5A). To insure that these results reflected a lack of DNA intercalation rather than an inhibition of topoisomerase-I enzyme activity, a second set of experiment was conducted using relaxed (i.e. negatively supercoiled) pBluescript plasmid DNA as initial substrate. BPT-treated negatively supercoiled DNA remained relaxed even after treatment with as high as $100 \mu \mathrm{M}$ concentration, whereas fascaplysin-treated negatively supercoiled DNA does not remain intact at low dose $(1 \mu \mathrm{M})$, clearly indicating the DNA-intercalating nature of the fascaplysin (Supplementary Figure S5B).

Cancer cell growth inhibition. Cancer cell growth inhibition data for BPT (6) and its structural analogues 3-5 is presented in Table 2. These compounds were tested in vitro in 10 cancer cell lines known to be relatively resistant to known chemotherapeutic agents. ${ }^{35}$ The inhibitory effects of compounds were quantified using MTT assay. The results of cell proliferation assays indicate that BPT inhibits the growth of cancer cells in vitro at submicromolar concentrations. Among all the analogues, BPT was found to be the most potent compound at the cellular level.

At its $I_{50}$ concentration, BPT arrests asynchronous cancer cells at the $\mathrm{G}_{2} / \mathrm{M}$ phase of the cell cycle (in $\mathrm{p53}^{+}$ A549 and p53 ${ }^{-} \mathrm{NCl}-\mathrm{H} 1299$ cells). When A549 (p53+) cells were treated with BPT ( $\mathrm{IC}_{50}$ concentration for $\left.24 \mathrm{~h}\right)$, a profound block at the $\mathrm{G}_{2} / \mathrm{M}$ phase was observed with $82 \%$ cells appearing to be in the $\mathrm{G}_{2} / \mathrm{M}$ phase (Figure $2 \mathrm{~b}$ ). At the 
<smiles>COc1ccccc1C(=O)N1CCc2c([nH]c3ccccc23)C1</smiles><smiles>COc1cccc(C(=O)N2CCc3c([nH]c4ccccc34)C2)c1</smiles>

b<smiles>O=C(O)c1ccccc1-c1ccccc1-c1cccc(-c2ccccc2)c1C(=O)N1CCc2c([nH]c3ccccc23)C1</smiles>

C

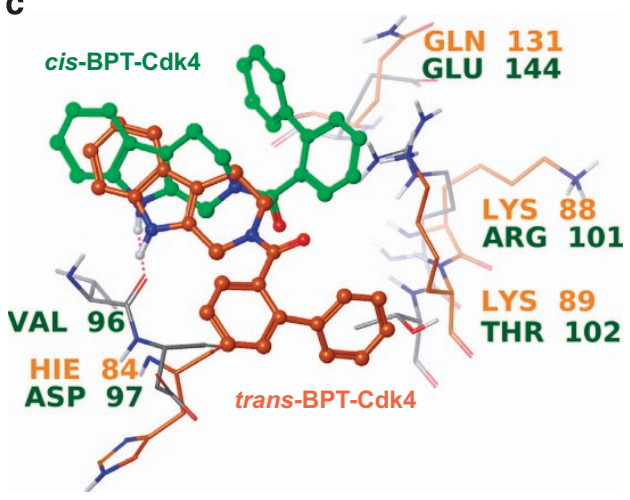

Figure 1 (a) Chemical structures of fascaplysin (1), CA224 (2) and its tryptoline analogues 3-6. (b) Synthetic scheme for BPT (6). (c) Molecular modelling studies to understand Cdk4 selectivity versus Cdk2: interactions of cis/trans conformations of BPT with Cdk2 and Cdk4, respectively (orange conformation is with Cdk2 and green with Cdk4)

Table 1 Activity of fascaplysin, BPT and other structural analogues in different in vitro kinase assays and DNA-binding (EtBr displacement) assay

\begin{tabular}{|c|c|c|c|c|c|}
\hline \multirow[t]{2}{*}{ In vitro bioassay } & \multicolumn{5}{|c|}{$\mathrm{IC}_{50}($ mean \pm S.D. $)(\mu \mathrm{M})$} \\
\hline & CA198 (3) & CA199 (4) & CA211 (5) & BPT (6) & Fascaplysin (1) \\
\hline Cdk4-cyclin D1 & $25 \pm 5.5$ & $24.4 \pm 4$ & $44 \pm 3$ & $10 \pm 1.2$ & $0.41 \pm 0.04$ \\
\hline Cdk2-cyclin A & $861 \pm 29$ & $766 \pm 33$ & $720 \pm 24$ & $831 \pm 15.5$ & $>250$ \\
\hline Cdk1-cyclin B1 & $>500$ & $>500$ & $>500$ & $>\overline{5} 00$ & $>250$ \\
\hline Cdk9-cyclin T1 & $>1000$ & $>1000$ & $>1000$ & $>1000$ & $>250$ \\
\hline Cdk5-p35 & ND & ND & ND & $\mathrm{NI}$ & ND \\
\hline Cdk6-cyclin D1 & ND & ND & ND & $\mathrm{NI}$ & ND \\
\hline Cdk7-cyclin H & ND & ND & ND & $\mathrm{NI}$ & ND \\
\hline EGFR & ND & ND & ND & $\mathrm{NI}$ & ND \\
\hline GSK3 $\beta$ & ND & ND & ND & $\mathrm{NI}$ & ND \\
\hline MAPK1 & ND & ND & ND & $\mathrm{NI}$ & ND \\
\hline MEK1 & ND & ND & ND & $\mathrm{NI}$ & ND \\
\hline PDGFR & ND & ND & ND & $\mathrm{NI}$ & ND \\
\hline Plk3 & ND & ND & ND & $\mathrm{NI}$ & ND \\
\hline PKA & ND & ND & ND & $\mathrm{NI}$ & ND \\
\hline $\mathrm{PKCa}$ & ND & ND & ND & $\mathrm{NI}$ & ND \\
\hline IGF-1 R & ND & ND & ND & $\mathrm{NI}$ & ND \\
\hline EtBr displacement & No EtBr displacement & No EtBr displacement & No EtBr displacement & No EtBr displacement & Displaces EtBr at \\
\hline assay & up to $100 \mu \mathrm{M}$ & up to $100 \mu \mathrm{M}$ & up to $100 \mu \mathrm{M}$ & up to $100 \mu \mathrm{M}^{\mathrm{a}}$ & $1 \mu \mathrm{M}$ \\
\hline
\end{tabular}

Abbreviations: ND, not determined; NI, no inhibition up to $10 \mu \mathrm{M}$

$I_{50}$ values are presented in $\mu \mathrm{M}$ concentration. The $\mathrm{IC}_{50}$ values presented here are means and S.D. from three independent experiments ${ }^{a}$ Detailed results of DNA-binding studies are provided in Section S5 of the Supplementary Information

$I_{70}$ concentration, $59 \%$ of cells were blocked at the $\mathrm{G}_{2} / \mathrm{M}$ phase and $13 \%$ of cells appeared as apoptotic, whereas $15 \%$ of cells remained in the $\mathrm{G}_{0} / \mathrm{G}_{1}$ phase (Figure $2 \mathrm{c}$ ). These results indicate that only at higher concentrations, BPT tends to act as a Cdk4 inhibitor blocking cells at the $\mathrm{G}_{0} / \mathrm{G}_{1}$ phase. At lower concentrations, greater tendency towards $G_{2} / M$ block is observed. Incubation of NCl-H1299 (p53-null) cells with the $\mathrm{IC}_{50}$ concentration of BPT resulted in a large 
number of cells (50\%) accumulating at the $\mathrm{G}_{2} / \mathrm{M}$ phase (Figure 2e). A549 and NCl-H1299 cells, which are blocked profoundly at the $\mathrm{G}_{2} / \mathrm{M}$ phase by BPT, have a functional mitotic-spindle checkpoint. However in p53-null Calu-1 cells (with 'non-functional' mitotic-spindle checkpoint), BPT, similar to compound $4,{ }^{30}$ blocks only at the $G_{0} / G_{1}$ phase as a consequence of Cdk4-cyclin D1 enzyme inhibition (Supplementary Figure S4).

BPT maintains nocodazole- and paclitaxel-induced $\mathrm{G}_{2} / \mathrm{M}$ block in $\mathrm{NCl}-\mathrm{H} 358$ lung cancer cells. To induce a partial block at the $\mathrm{G}_{2} / \mathrm{M}$ phase so that cells are minimally stressed, p53-null $\mathrm{NCl}-\mathrm{H} 358$ cells were treated with suboptimal concentrations of nocodazole $(1 \mu \mathrm{M})$ for $18 \mathrm{~h}$. The blocked cells were released in the fresh medium when they readily entered the cell cycle without any apoptosis. In the presence of BPT, however, cells not only maintain the $\mathrm{G}_{2} / \mathrm{M}$ block but also $>50 \%$ of the $\mathrm{G}_{0} / \mathrm{G}_{1}$ - and $\mathrm{S}$-phase cells enter the $\mathrm{G}_{2} / \mathrm{M}$ phase (Figures $2 \mathrm{f}-\mathrm{i}$ ) within $12 \mathrm{~h}$. Although only representative histograms related to nocodazole treatment are shown, similar results were obtained when paclitaxel-blocked cells were released for $12 \mathrm{~h}$ in the presence of BPT.

$\mathrm{G}_{2} / \mathrm{M}$ block of $\mathrm{NCl}-\mathrm{H} 358$ cells by BPT, after release from hydroxyurea-mediated $\mathrm{G}_{1} / \mathrm{S}$ cell synchronization. Hydroxyurea is known to block cell growth at the $\mathrm{G}_{1} / \mathrm{S}$ boundary. Incubation with $250 \mu \mathrm{M}$ hydroxyurea for $18 \mathrm{~h}$ caused a block of $\mathrm{NCl}-\mathrm{H} 358$ cells at the $\mathrm{G}_{1} / \mathrm{S}$ phase $(77 \%$ cells were at the $G_{1}$ phase; Figure $2 \mathrm{~g}$ ), at a stage of the cell cycle where Cdk2-specific inhibitors normally act. When released in the presence of BPT, cells proceed from the $G_{1} / S$ phase, confirming that BPT does not inhibit cellular Cdk2. Cells ultimately accumulate at the $G_{2} / M$ phase (72\%; Figure $2 \mathrm{~m}$ ). Cells released in the fresh medium enter the cell cycle (Figure $2 \mathrm{k}$ ). These results again indicate that BPT has an inherent tendency to induce block at the $\mathrm{G}_{2} / \mathrm{M}$ phase.

BPT selectively induces apoptotic cell death in SV40-large T-antigen-transformed normal mouse embryonic liver cells. SV40-large T-antigen inactivates both the tumour suppressor proteins p53 and pRb, and thereby transforms normal cells into tumorigenic cells. The effect of BPT on normal mouse embryonic hepatic (liver) cells BNL CL2 and its SV40-large T-antigen-transformed counterpart BNL SV A.8 was investigated. More than $50 \%$ normal cells appeared in the $\mathrm{G}_{2} / \mathrm{M}$ phase of the cell cycle upon $48 \mathrm{~h}$ incubation with $\mathrm{IC}_{50}$ and $\mathrm{IC}_{70}$ concentrations of BPT; however, only $<10 \%$ cells were detected in the sub- $\mathrm{G}_{1}$ phase (Figure 2o). Interestingly, in the SV40-transformed cell line, significant apoptotic cell death was observed, which is represented by the percentage of cells appearing in the sub$\mathrm{G}_{1}$ phase. After $48 \mathrm{~h}$ treatment with $\mathrm{IC}_{50}$ concentration of

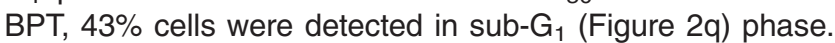
The percentage of apoptosis was increased to $51 \%$ at the $\mathrm{IC}_{70}$ concentration. Long-term cell survival assay in mouse embryonic normal hepatic cell line (BNL CL2) and SV40mediated transformed mouse embryonic hepatic cell line (BNL SV A.8) after the treatment with BPT indicated that it selectively reduces the number of colonies in SV40-mediated

Table $2 \mathrm{IC}_{50}$ concentrations expressed in $\mu \mathrm{M}$ for the in vitro cell growth inhibition induced by exposure to fascaplysin (1), CA198 (3), CA199 (4), CA211 (5) and BPT (6) for $48 \mathrm{~h}$ and measured by MTT assay

\begin{tabular}{|c|c|c|c|c|c|}
\hline Cell lines & Fascaplysin (1) & CA198 (3) & CA199 (4) & CA211 (5) & BPT (6) \\
\hline LS174T (colorectal carcinoma; p53+, pRb+) & $0.88+0.04$ & $33+2.5$ & $7.1+1.3$ & $29+2$ & $0.85+0.07$ \\
\hline PC-3 (prostate; p53 null, pRb+) & $0.92+0.06$ & $42+3$ & $13.1+1.8$ & $32+1.5$ & $0.74+0.09$ \\
\hline MiaPaCa (pancreatic; p53His273mut, pRb+) & $0.88+0.2$ & $43+5$ & $8.5+1.3$ & $29+4.5$ & $0.8+0.1$ \\
\hline A549 (NSCLC; p53+, pRb+) & $0.69+0.03$ & $46+4$ & $8.0+2$ & $31+3.5$ & $0.92+0.08$ \\
\hline Calu-1 (NSCLC; p53 null, pRb+) & $1.3+0.1$ & $92+4.5$ & $47+3.5$ & $54+4$ & $2.8+0.4$ \\
\hline $\mathrm{NCl}-\mathrm{H} 460$ (NSCLC; p53+, pRb+) & ND & $29+3.5$ & $6.2+0.7$ & $22+2$ & $0.6+0.06$ \\
\hline NCI-H1299 (NSCLC; p53 null, pRb+) & ND & $35+2$ & $4.5+0.5$ & $30+1$ & $0.9+0.045$ \\
\hline NCI-H358 (NSCLC; p53 null, pRb null) & ND & $28+4$ & $3.5+0.8$ & $25+1.5$ & $0.68+0.07$ \\
\hline BNL CL2 (mouse normal hepatic cells) & ND & $37+1.5$ & $6.5+0.7$ & $27+2.5$ & $0.72+0.1$ \\
\hline BNL SV A.8 (mouse hepatic; SV40-mediated transformed cells) & ND & $40+3.5$ & $8.2+1$ & $35+3$ & $0.75+0.08$ \\
\hline
\end{tabular}

All results represent means and S.D. from at least three independent experiments

\footnotetext{
Figure 2 (a-e) Response of mitotic-spindle checkpoint-proficient human lung cancer cell lines, A549 and NCl-H1299, to BPT. Flow cytometric analysis of asynchronous cells show that majority of cells are arrested in the $\mathrm{G}_{2} / \mathrm{M}$ phase of cell cycle (4nDNA content) in both the cell lines. $A 549$ untreated (a), treatment with $\mathrm{C}_{50}$ concentration of $B P T$ for $24 \mathrm{~h}$ (b) and treatment with $\mathrm{IC}_{70}$ concentration of BPT for $24 \mathrm{~h} \mathrm{(c);} \mathrm{NCl}-\mathrm{H} 1299$ untreated or control (d) and treatment with $\mathrm{IC}_{50}$ concentration of $\mathrm{BPT}$ for $24 \mathrm{~h}$ (e). (f-m) Analysis of NCl$\mathrm{H} 358$ cells using flow cytometer. Cells in the $\mathrm{G}_{2} / \mathrm{M}_{\text {and }} \mathrm{G}_{1} / \mathrm{S}$ phase synchronized by nocodazole and hydroxyurea, respectively, were released either in the fresh medium or in the fresh medium containing $\mathrm{IC}_{50}$ concentration of BPT, which exhibit greater tendency to block the cell growth at the $\mathrm{G}_{2} / \mathrm{M}$ phase. For nocodazole block experiment, figure show untreated or control cells $(\mathbf{f})$, treated with $1 \mu \mathrm{M}$ nocodazole for $18 \mathrm{~h}(\mathrm{~g})$, treated with $1 \mu \mathrm{M}$ nocodazole for $18 \mathrm{~h}$ and released in the fresh medium (h) and treated with $1 \mu \mathrm{M}$ nocodazole for $18 \mathrm{~h}$ and released in the presence of $\mathrm{BPT}, \mathrm{IC}_{50}$ (i). For hydroxyurea block experiment, the figure shows untreated or control cells (j), treated with $250 \mu \mathrm{M}$ hydroxyurea for $18 \mathrm{~h}(\mathbf{k})$, treated with $250 \mu \mathrm{M}$ hydroxyurea for $18 \mathrm{~h}$ and released in the fresh medium (I) and treated with $250 \mu \mathrm{M}$ hydroxyurea for $18 \mathrm{~h}$ and released in the presence of BPT, IC $I_{50}(\mathbf{m})$. (n-q) Selective apoptosis in SV40-transformed cells by BPT was analysed by FACS. BNL CL2 (mouse embryonic normal hepatic cells) when exposed to $B P T$ for $48 \mathrm{~h}$ at $I C_{50}$ and $I C_{70}$ concentrations show prominent $\mathrm{G}_{2} / \mathrm{M}$ arrest. As seen in the figure, untreated cells $(\mathrm{n})$, treated with IC ${ }_{50}$ concentration of $B P T, 48 \mathrm{~h}(\mathbf{0})$. BNL SV A.8 (mouse embryonic SV40-transformed hepatic cells) underwent apoptotic cell death upon incubation with BPT. The apoptosis was quantitated by measuring the \% of cells that appeared in sub- $\mathrm{G}_{1}$ peak; 43 and $51 \%$ cells were found in sub- $\mathrm{G}_{1}$ peak after $48 \mathrm{~h}$ exposure with $\mathrm{BPT}, \mathrm{IC}_{50}(\mathbf{q})$ concentration. The untreated cells (p) do not show any apoptosis
} 
transformed mouse embryonic hepatic cell line (BNL SV A.8) upon 12 days treatment but not in mouse embryonic normal hepatic cell line (BNL CL2) as shown in Supplementary Figure S3.
Effect of BPT on the levels of cyclin B1, Cdk1, p53, p21 ${ }^{\text {CIP1/WAF1 }}$ (p21) and p27 ${ }^{\mathrm{KIP} 1}$ (p27) in p53+ cells. Western blot analyses of p53+ A549 and LS174T cells, after treatment with BPT at the $I_{50}$ concentration for $24 \mathrm{~h}$,

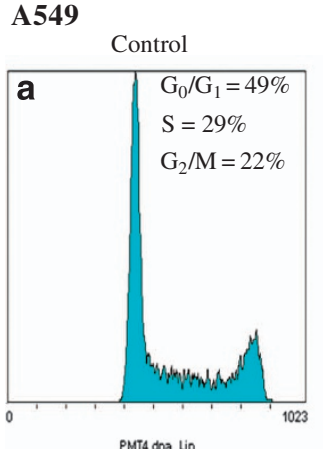

NCI-H358

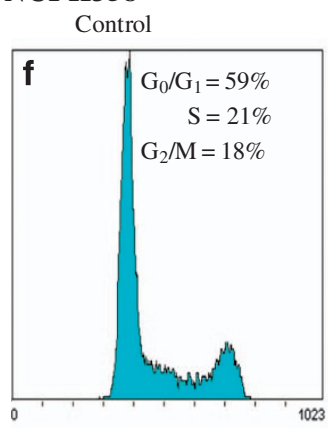

PMT4 dina Lin

\section{$\mathrm{NCl}-\mathrm{H} 358$}

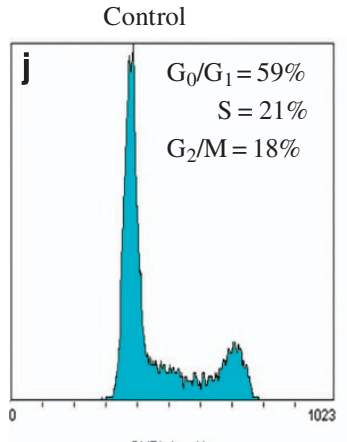

PMT4 dna Lin

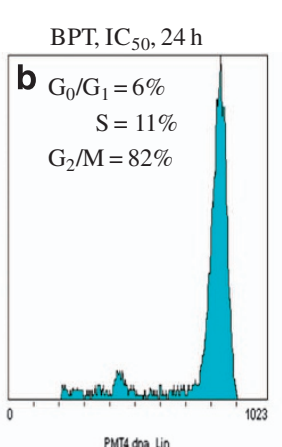

PMTA dong lin

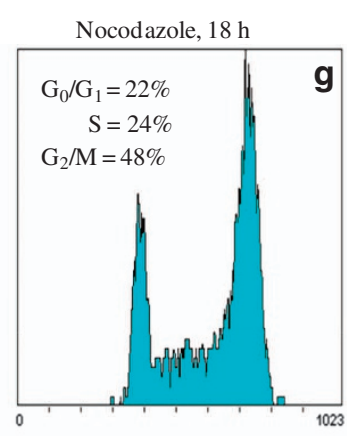

PMT4 dna Lin

Hydroxyurea, $250 \mu \mathrm{M}, 18 \mathrm{~h}$

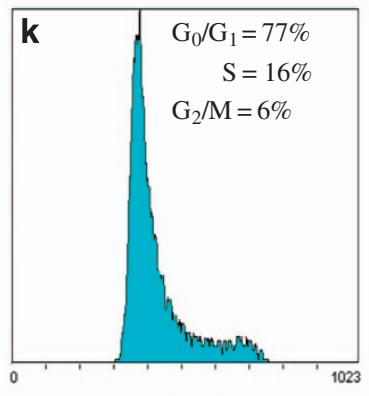

PMTA dna Lin

BNL CL2 (mouse normal hepatic cell line)

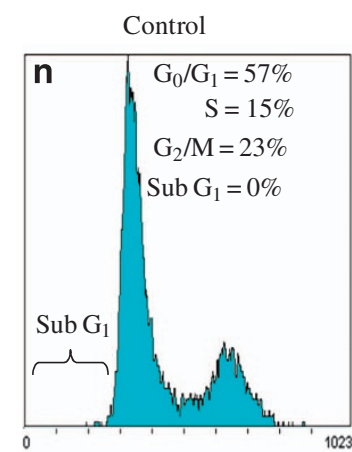

PMT4 dna lin
BPT, $\mathrm{IC}_{50}, 48 \mathrm{~h}$

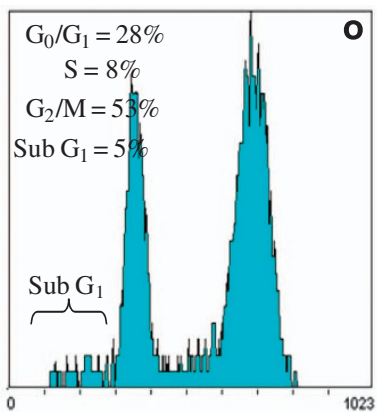

PMT4 dna Lin

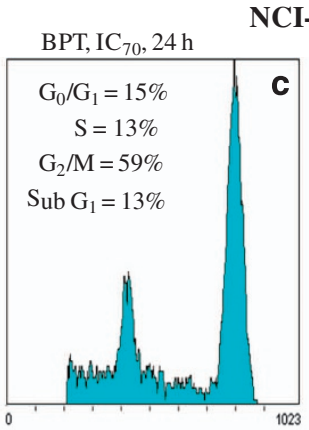

PMT4 dina Lin

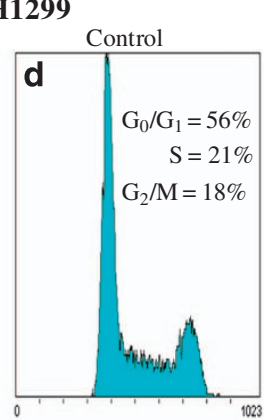

PMT4 ona lin

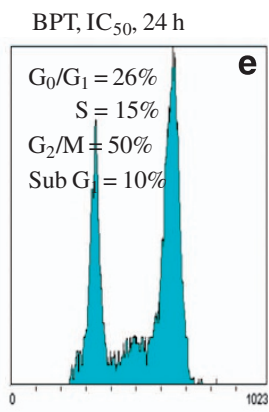

PMT4 ona lin

Nocodazole, 18 h; Released in medium, $12 \mathrm{~h}$

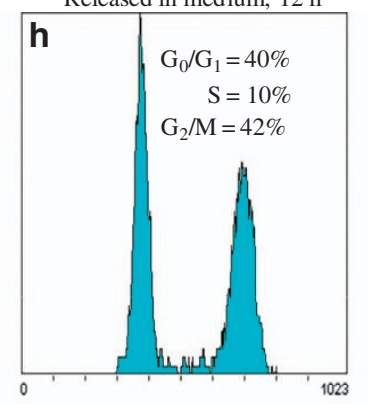

PMT4 dna Lin

Hydroxyurea, $250 \mu \mathrm{M}, 18 \mathrm{~h}$ Released in fresh medium, $18 \mathrm{~h}$

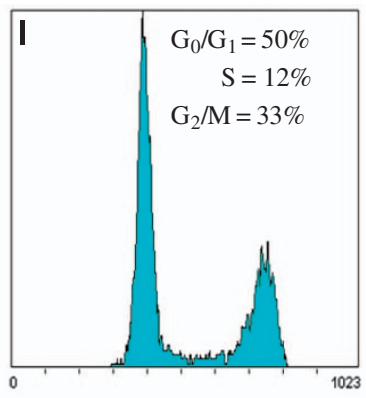

PMT4 dna Lin
Nocodazole, $18 \mathrm{~h}$;

Released in BPT, $\mathrm{IC}_{50}, 12 \mathrm{~h}$

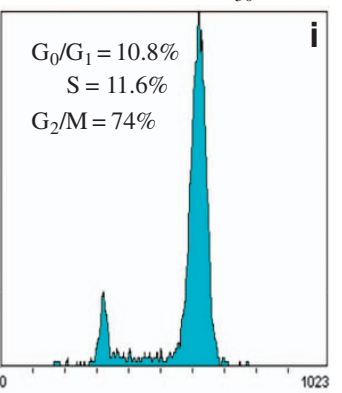

PMT4 dna lin

Hydroxyurea, $250 \mu \mathrm{M}, 18 \mathrm{~h}$ Released in BPT, $\mathrm{IC}_{50}, 18 \mathrm{~h}$

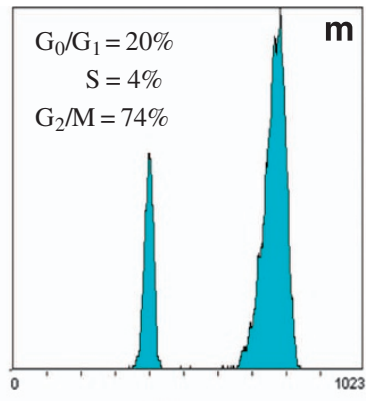

PMT4 dna lin

BNL SV A. 8 (mouse SV40 transformed hepatic cell li

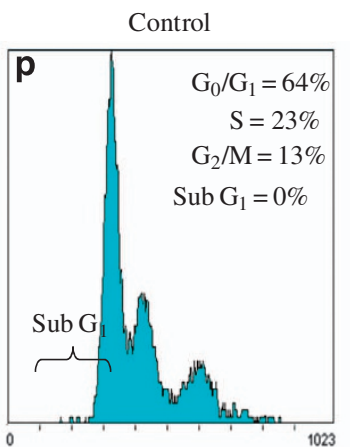

PMT4 dna Lin

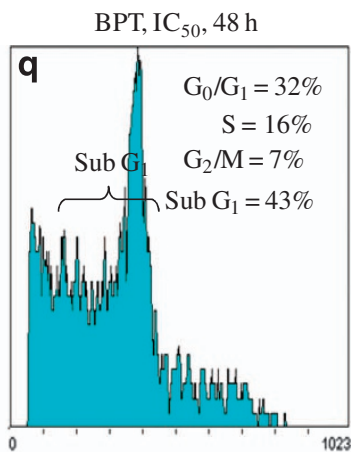

PMTA dna Lin 
demonstrated more than 10-fold induction of p53, which corresponds with increase in levels of the Cdk global inhibitor $\mathrm{p} 21^{\mathrm{CIP} 1 / \mathrm{WAF} 1}(\mathrm{p} 21)$. The levels of the other pan-Cdk inhibitor p27 $7^{\mathrm{KIP} 1}$ (p27) were also elevated owing to BPT treatment (Figure 3). The proteins Cdk1 and cyclin B1 were downregulated in the treated cells as compared with untreated control cells (Figure 3).

Effect of BPT on the levels of cyclin B1, Cdk1, p53, p21 and p27 in mutant p53 cells. Western blot experiments were performed to ascertain the levels of cell cycle regulatory proteins in MIAPaCa cells, which contain p53 gene mutations (data not shown). Upon BPT treatment, p53, p21 and p27 levels remained unchanged, suggesting that the p21 and p27 induction is probably p53-dependent. The MiaPaca cell line has mutated p53 and proteins p21 and p27 are controlled by p53 pathway. The inhibition of cell growth by BPT was independent of the presence or absence of tumour suppressor protein p53, owing to which there was unchanged expression of these proteins after treatment with BPT. Interestingly, the cyclin B1 and Cdk1 levels were elevated and Tyr15 residue of Cdk1 remained dephosphorylated, indicating that Cdk1-cyclin B1 is still active in p53-mutated cells after BPT treatment.

In p53+ cancer cells, BPT downregulates cyclin B1 and Cdk1 but upregulates the pan-Cdk inhibitory proteins p21 and p27. This provides a mechanistic insight into the block of cell growth explaining why p53+ cells undergo block at the $\mathrm{G}_{0} / \mathrm{G}_{1}$,

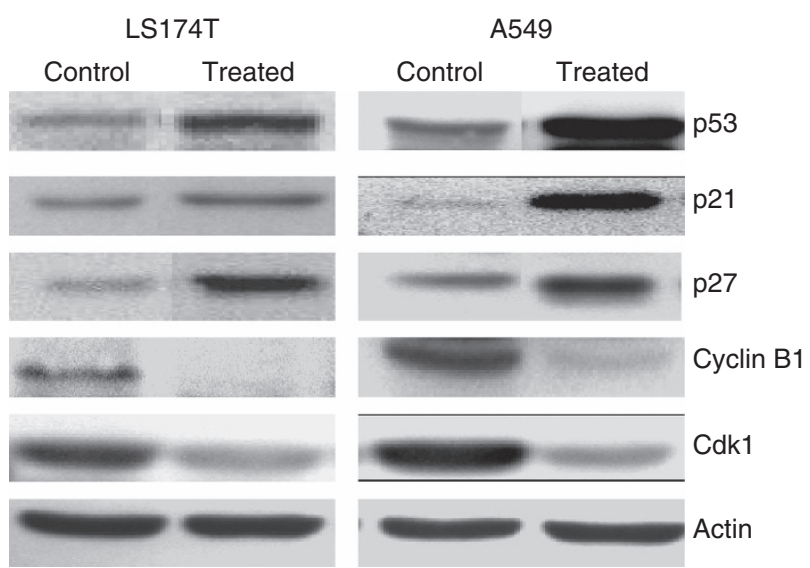

Figure 3 A549 and LS174T cells were analysed by western blot technique. The treatment of $p 53+$ cells (A549 and LS174T) with BPT at IC 50 concentration for $24 \mathrm{~h}$ resulted in induction of p53, p21 ${ }^{\text {CIP1/NAF1 }}$ (p21) and p27 $7^{\mathrm{KIP1} 1}$ (p27), whereas cyclin B1 and Cdk1 levels were downregulated
$\mathrm{G}_{2}$ and $\mathrm{M}$ phases of the cell division cycle. BPT upregulates cyclin B1 levels both in p53-mutant and p53-null cells (data not shown), indicating that in these cancer cells the major block occurs at a post- $G_{2}$ phase of the cell cycle. This is likely to happen in between the $G_{2}$ and the $G_{0} / G_{1}$ phases of the cell cycle, suggesting that BPT somehow affects the functions of mitosis.

Inhibition of tubulin polymerization in vitro by BPT. BPT inhibits the polymerization of tubulin, which is concluded from the dose-dependent decrease in $V_{\max }(\mathrm{mOD} / \mathrm{min})$ and reduction in final polymer mass (Figure 4a). When tested at four different concentrations, BPT decreased the $V_{\max }$ from $19 \mathrm{mOD} / \mathrm{min}$ to $12.5,9.2,3$ and $0.5 \mathrm{mOD} / \mathrm{min}$ at $0.5,1,2.5$ and $5 \mu \mathrm{M}$ of $\mathrm{BPT}$, respectively. As a consequence of decreased $V_{\max }$, up to $80 \%$ reduction in final polymer mass was observed. Interactions of BPT with tubulin are shown in Supplementary Figure S1.

Enhancement of tubulin depolymerization and inhibition of tubulin polymerization in the presence of BPT in live cells. A549 cells were used to explore the interactions between BPT and tubulin protein in live cells. As the mitoticspindle checkpoint in A549 cells is intact, these cells are sensitive to antimicrotubule agents. The assembled (cytoskeletal) and unassembled (cytosolic) forms of tubulin were determined, via western blotting, from their accumulation and disappearance from pellet and supernatant fractions of the cell lysates, after cells were treated with BPT. Paclitaxel treatment of A549 cells for 30 min resulted in the accumulation of cytoskeletal tubulin as a consequence of enhanced tubulin polymerization, whereas in the presence of BPT the paclitaxel-mediated polymerization is inhibited in a dosedependent manner (Figure 4b). More interestingly, when intracellular stabilized tubulin (paclitaxel-treated cells) was subjected to BPT treatment, BPT enhanced the tubulin depolymerization, resulting in the disappearance of cytoskeletal tubulin (pellet) form and accumulation of cytosolic tubulin (supernatant) form (Figure $4 b$ ).

Clonogenic assay. The effects of BPT on colony formation efficiency of p53+ A549 and p53-null Calu-1 cells were investigated. Calu-1 cells, similar to A549, contain a functional $p R b$ protein but, in contrast to A549 cells, have a defective mitotic-spindle checkpoint. ${ }^{36}$ The concentration at which BPT prevented colony formation (in a 12-day experiment) was found to be relatively lower than the concentration at which it inhibited cell proliferation ( $48 \mathrm{~h}$ experiment). This could be because very few cells in the total population retain

\footnotetext{
Figure 4 (a) Cell-free tubulin polymerization assay in vitro. Purified tubulin was used to test the ability of BPT to inhibit tubulin polymerization in vitro. The assay measures the increase in optical density as a result of tubulin assembly or polymerization. Nocodazole and paclitaxel were used in the assay as a known inhibitor and enhancer of tubulin polymerization. BPT was tested at four different concentrations that show inhibition of cell growth in vitro. The change in $V_{\max }$ value was used as an indicator of tubulin/ligand interactions. The polymerization curves indicate $0.5,1,2.5$ and $5 \mu \mathrm{M}$ of BPT reduced the $V_{\max }$ value from $19 \mathrm{mOD} / \mathrm{min}$ (control) to $12.5,9.2,3$ and $0.5 \mathrm{mOD} / \mathrm{min}$, respectively, in a dose-dependent manner. The curves shown represent the average of three independent experiments. (b) Inhibition of tubulin polymerization and enhancement of tubulin depolymerization in live cells. The tubulin polymerization assay was performed in A549 (whole cells) after 30 min compound treatment at the concentrations indicated in the figure. Supernatant and pellet represent unassembled and assembled tubulin, respectively. Tubulin polymerization is detectable by the increase of tubulin in pellet and its disappearance from supernatant. The western blots show dose-dependent inhibition of tubulin polymerization after the simultaneous treatment of paclitaxel and BPT that resulted in the accumulation of unassembled tubulin in supernatant. BPT also acts as an enhancer for tubulin depolymerization in a dose-dependent manner when paclitaxel-stabilized tubulin was subjected to BPT treatment for $30 \mathrm{~min}$
} 
the ability to maintain cell division cycles, which could eventually result in non-detectable colonies of cells. BPT shows significant reduction in the colony formation efficiency of both p53+ and p53-null cancer cells in vitro (Figure 5).

In vivo experiments in mice: pharmacokinetics and determination of MTD. The pharmacokinetics of BPT was carried out in BALB/c mice at $10 \mathrm{mg} / \mathrm{kg}$ (per os) and
$1.0 \mathrm{mg} / \mathrm{kg}$ (intravenous) dose, which showed $\mathrm{AUC}_{0-t}$ of 17.7 and $170 \mathrm{ng} \cdot \mathrm{h} / \mathrm{ml}$, respectively. The $\mathrm{PK}$ parameters after intravenous dosing were: $t_{1 / 2}=0.19 \mathrm{~h}, C_{\max }: 413 \mathrm{ng} / \mathrm{ml}$, $\mathrm{C}_{0}: 888 \mathrm{ng} / \mathrm{ml}, \mathrm{AUC}_{0-t}=170 \mathrm{ng} \bullet \mathrm{h} / \mathrm{ml}, \mathrm{AUC}_{0_{-} \infty}: 174 \mathrm{ng} \bullet \mathrm{h} / \mathrm{ml}$, CL: $95.8 \mathrm{ml} / \mathrm{min}$ per $\mathrm{kg}$ and $V_{\mathrm{d}}: 1.56 \mathrm{l} / \mathrm{kg}$. Because of the poor oral bioavailability of BPT, we decided to perform in vivo efficacy via intraperitoneal route. The in vivo study to determine maximum-tolerated dose (MTD) was performed in a

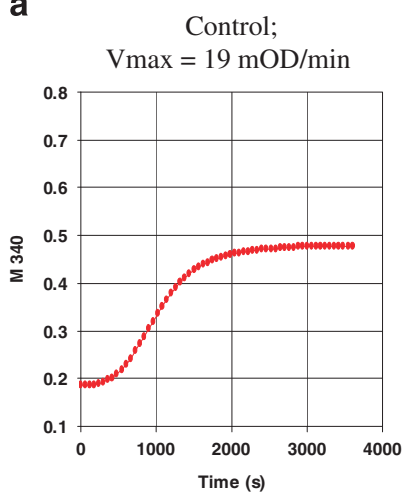

BPT, $0.5 \mu \mathrm{M}$;

$\mathrm{V} \max =12.5 \mathrm{mOD} / \mathrm{min}$

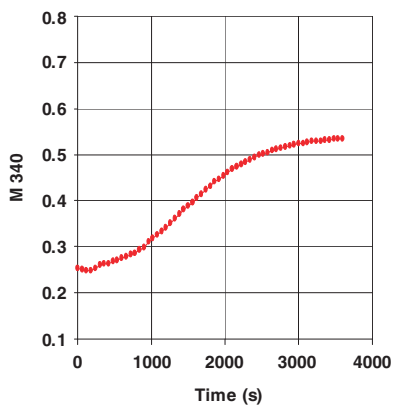

paclitaxel, $10 \mu \mathrm{M}$; $\mathrm{V} \max =61 \mathrm{mOD} / \mathrm{min}$

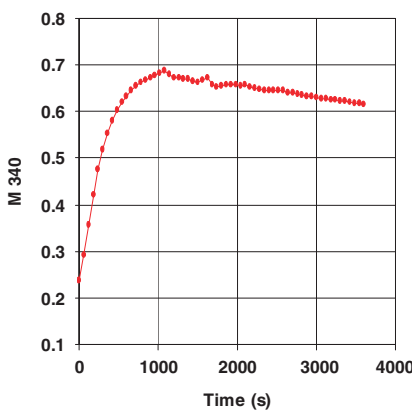

BPT, $1 \mu \mathrm{M}$

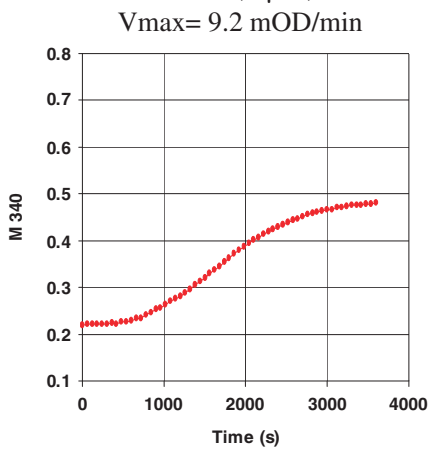

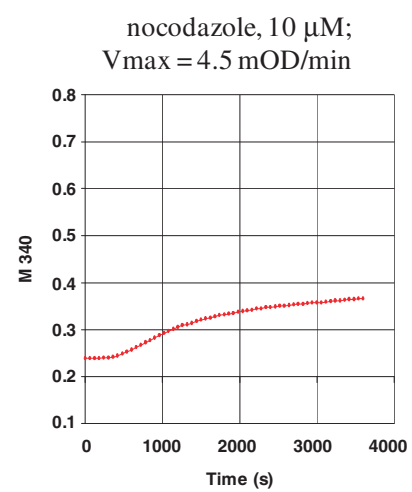

BPT, $2.5 \mu \mathrm{M}$;

$\mathrm{V} \max =3 \mathrm{mOD} / \mathrm{min}$

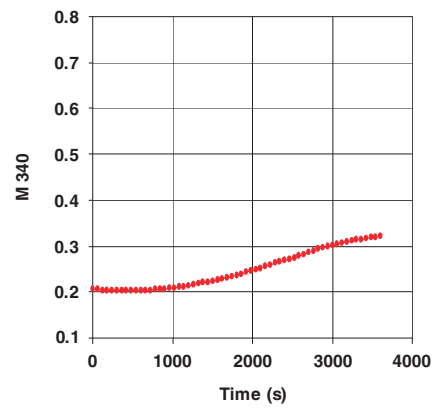

\section{Tubulin}

polymerization

assay in vitro
$\mathrm{BPT}, 5 \mu \mathrm{M}$;

$\mathrm{V} \max =0.5 \mathrm{mOD} / \mathrm{min}$

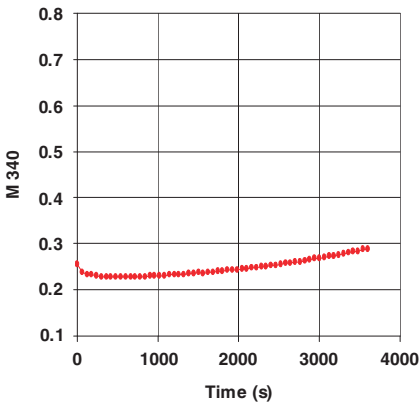

b

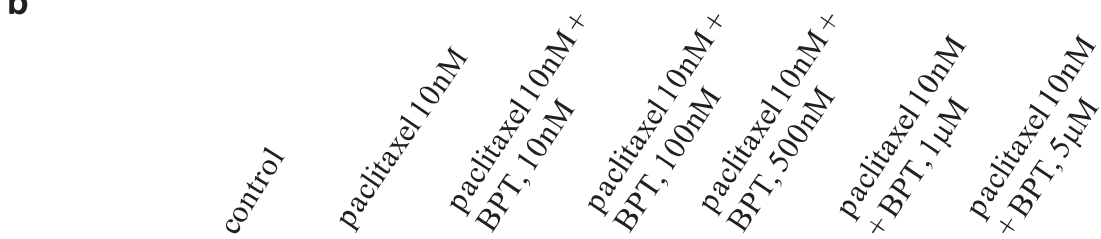

supernatant

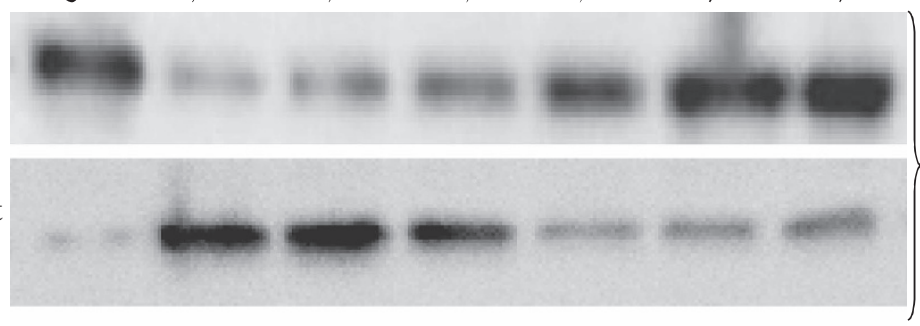

supernatant

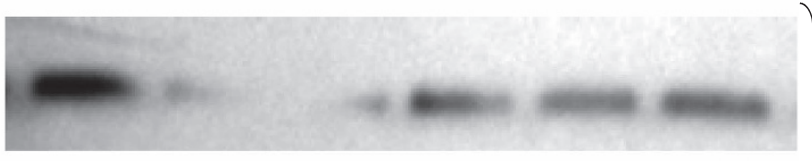

simultaneous

treatment of

paclitaxel and

BPT

pellet

paclitaxel

treatment

followed by

BPT 
A
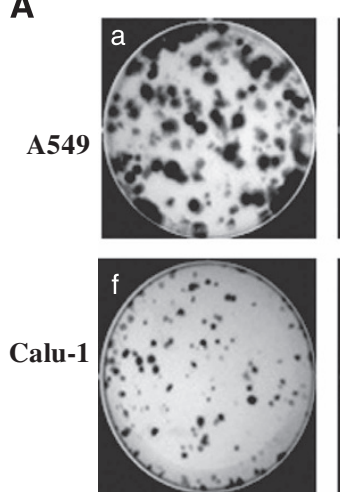
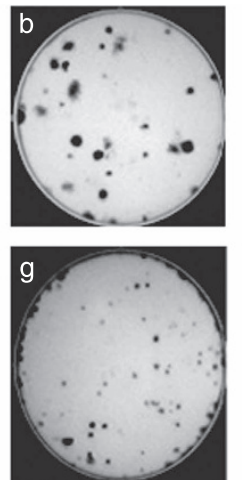
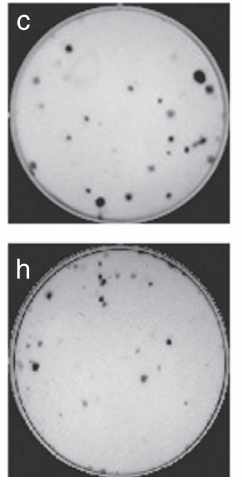
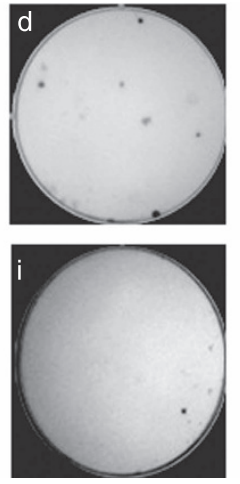
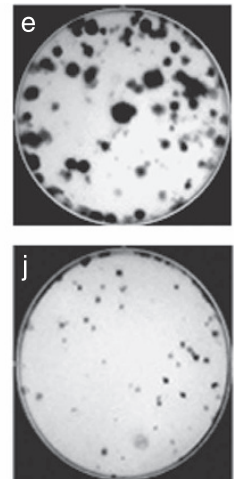

B

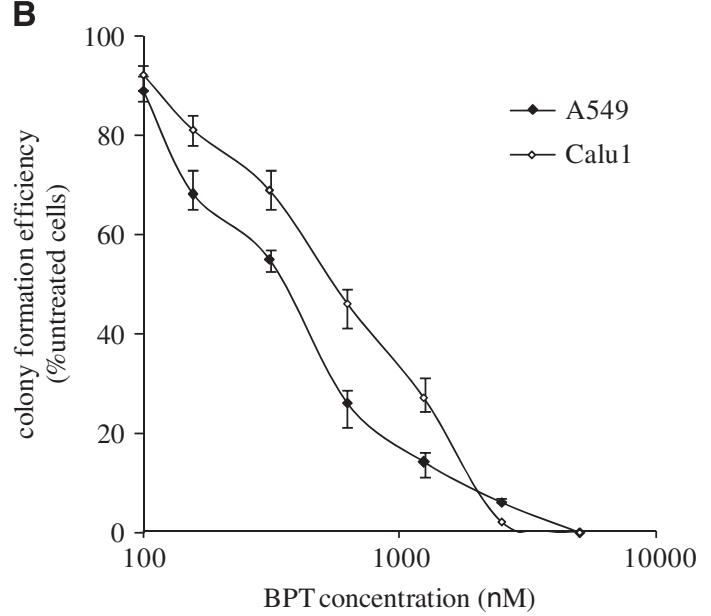

Figure 5 Long-term survival of cancer cells after the treatment with BPT. A549 and Calu-1 cells were investigated for their long-term survival efficiency after treatment with different concentrations of BPT. The colony formation efficiency is expressed as the percentage of colonies formed in the treated cultures compared with untreated cultures. (A) The representative plates show A549 untreated (a), treated with BPT, $0.5 \mu \mathrm{M}(\mathrm{b})$, treated with BPT, $1 \mu \mathrm{M}(\mathrm{c})$, treated with BPT, $2.5 \mu \mathrm{M}(\mathrm{d})$ and treated with fascaplysin, $0.8 \mu \mathrm{M}(\mathrm{e})$; Calu-1 untreated (f), treated with BPT, $0.5 \mu \mathrm{M}(\mathrm{g})$, treated with BPT, $1 \mu \mathrm{M}(\mathrm{h})$, treated with BPT, $2.5 \mu \mathrm{M}$ (i) and treated with fascaplysin, $1 \mu \mathrm{M}$ (j). (B) The curves representing colony formation efficiencies of A549 and Calu- 1 cells with increasing concentrations of BPT. All results are represented by means \pm S.D. obtained from three independent experiments

Swiss-albino mice over 2 weeks. Loss in animal body weight was considered as a measure of overtoxicity for the test compound. The concentration of the compound at which $\geq 10 \%$ weight loss was observed was determined and designated as MTD, although usually a weight loss, which is below $20 \%$ of the initial weight, is considered harmless as animals can recover once the treatment is stopped. The toxicity results obtained from these studies indicated that for BPT, the MTD in mice was $\sim 1000 \mathrm{mpk}$ (milligrams per kilogram of body weight).

Effects on growth of tumours derived from HCT-116 and $\mathrm{NCl}-\mathrm{H} 460$ cell lines. SCID mice, lacking both $\mathrm{T}$ and $\mathrm{B}$ immune cells, are an established model to study in vivo efficacy of potential anticancer agents. Flavopiridol $(2.5 \mathrm{mpk})$ was used as positive control in both xenograft models (Supplementary Figure S8). When evaluated, BPT showed statistically significant $(P<0.05)$ tumour growth inhibition (Figure 6a) at 1/10th of MTD concentration (100 mpk) in the HCT-116 tumour model. The data for BPT at 250 and $500 \mathrm{mpk}$ is provided in Supplementary Figure S7. Mice injected with BPT exhibited $\sim 80 \%$ tumour growth inhibition as compared with the untreated mice injected with the vehicle solution alone. A second set of SCID mice experiments, using tumours formed from $\mathrm{NCl}-\mathrm{H} 460$ cells, confirmed the antitumour potential of BPT when it again showed high efficacy at $100 \mathrm{mpk}$ concentration (Figures $6 \mathrm{~b}-\mathrm{d}$ ). In both tumour models, treated animals displayed statistically insignificant weight loss (Supplementary Figure S6).

\section{Discussion}

BPT, a non-planar analogue of fascaplysin, showed selective inhibition of Cdk4 with an $\mathrm{IC}_{50}$ of $10 \mu \mathrm{M}$, showing no inhibition against other kinases including Cdks at $10 \mu \mathrm{M}$. It does not intercalate DNA, which makes it free from unusual toxicity of DNA-intercalating agents. In cellular assays, BPT displays potent cytotoxicity in several cell lines. Considering the p53 and $\mathrm{pRb}$ status of the cancer lines tested, it is clear that inhibition of cell growth was p53- and pRb-independent. BPT showed cytotoxicity in p53-null (PC-3, Calu-1, NCl-H1299, $\mathrm{NCl}-\mathrm{H} 358$ ) as well as p53-positive cells (LS174T, A549, NCl$\mathrm{H} 460)$. Furthermore, it also showed cytotoxicity in pRbpositive as well as pRb-null cells, indicating that inhibition of cell growth was independent of the presence or absence of tumour suppressor proteins p53 and pRb. High potency of 
a

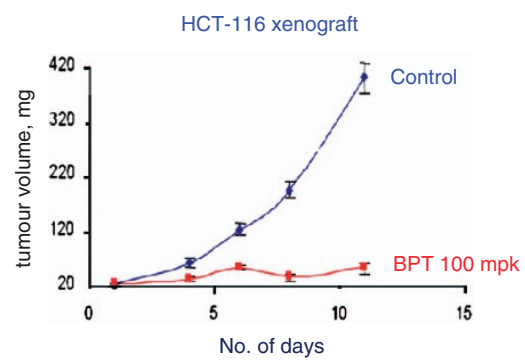

Control mice with $\mathrm{NCl}-\mathrm{H} 460$ xenografts

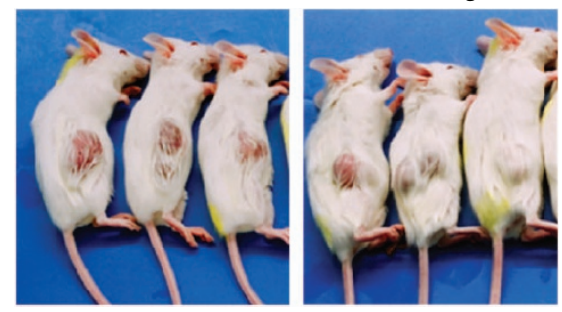

C Mice treated with $\mathrm{BPT}, 100 \mathrm{mpk}$

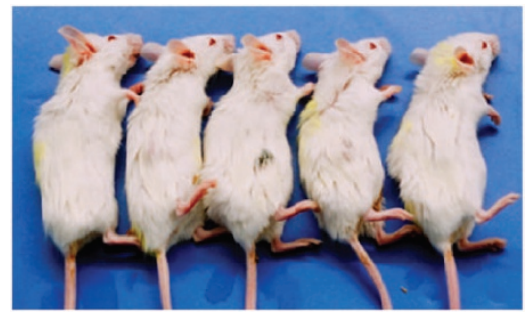

b

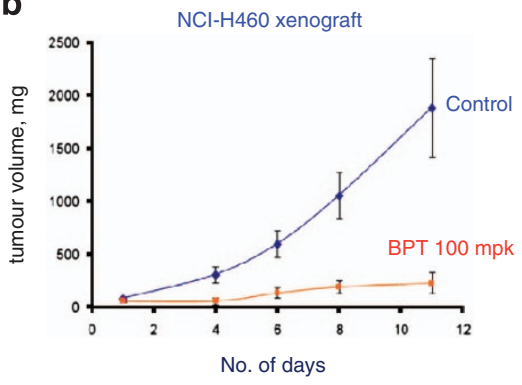

Tumour tissues removed from control mice

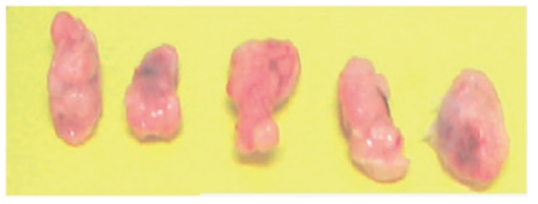

d

Tumour tissues removed from mice treated with BPT, $100 \mathrm{mpk}$

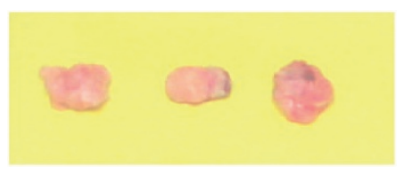

Figure 6 (a) In vivo tumour growth inhibition curve for BPT in the SCID mice-HCT-116 xenograft model. Graphs depict tumour growth inhibition in a group of animals treated with BPT at the concentration $100 \mathrm{mpk}$, which is compared with the untreated group of animals (shown in the graphs as the control group). Tumour sizes were recorded at 2-5 day intervals. Tumour weight (in $\mathrm{mg}$ ) was estimated according to the formula for a prolate ellipsoid: (length $(\mathrm{mm}) \times\left(\right.$ width $\left.\left.(\mathrm{mm})^{2}\right) \times 0.5\right)$ assuming specific gravity to be one and $\pi$ to be three. (b) Tumour growth inhibition curves for BPT in the SCID mice-NCI-H460 xenograft model. Graphs depict tumour growth inhibition in a group of animals treated with BPT compared with the untreated group of animals (shown in the graphs as the control group). Tumour sizes were recorded at $2-5$ day intervals. Tumour weight (in mg) was estimated according to the formula for a prolate ellipsoid: (length $(\mathrm{mm}) \times\left(\right.$ width $\left.\left.(\mathrm{mm})^{2}\right) \times 0.5\right)$ assuming specific gravity to be 1 and $\pi$ to be 3 . (c) The pictures of SCID mice showing $\mathrm{NCl}-\mathrm{H} 460$ tumour growth inhibition followed by treatment with BPT at the concentration $100 \mathrm{mpk}$. The treatments were continued for 9 consecutive days intraperitoneally when tumour growth had reached about 4-6 mm in diameter after about 6 days following the tumour cell injection. (d) Pictures of NCI-H460 tumour tissues, from SCID mice, exhibiting tumour growth inhibition by BPT

BPT in cell lines that lack pRb activity (i.e. $\mathrm{NCl}-\mathrm{H} 358$ that is pRb-null) suggests that Cdk4 inhibition may not be the only cellular target of BPT. It exhibits G2/M block of $\mathrm{NCl}-\mathrm{H} 358$ cells, which again indicates that BPT has an inherent tendency to induce block at the $\mathrm{G} 2 / \mathrm{M}$ phase. The cell cycle studies indicated that BPT blocks the $\mathrm{G}_{0} / \mathrm{G}_{1}$ phase of the cell division cycle as would be expected of a true Cdk4 inhibitor, but only partially. However, it profoundly blocks cells at the $G_{2} / M$ phase at comparatively low concentrations. $\mathrm{G}_{2} / \mathrm{M}$ arrest could be the result of cellular stress. In response to cellular stress, induction of the p53 protein may arrest cells at the $G_{2} / M$ phase. ${ }^{37}$ However, in p53-null NCl-H358 cells, the prometaphase block induced by nocadozole or paclitaxel is maintained by BPT. The G2/M block seems to be p53-independent. The selective cell death induction in cancer cells by BPT is very significant. From the results of cell cycle (Figures $2 n-q$ ), percent cell death and apoptosis (Supplementary Figure S2), and colony formation assay (Supplementary Figure S3), it was also observed that BPT selectively induces apoptosis in SV40-large T-antigentransformed cells and not in -untransformed normal cells.
A number of compounds, which are particularly potent Cdk2 inhibitors, have been reported to induce apoptosis selectively in transformed cells. ${ }^{38-40}$ Relatively low doses of celecoxib has been reported to induce $\mathrm{G}_{2} / \mathrm{M}$ arrest, followed by induction of apoptosis only in transformed cells but not in normal cells. Celecoxib also downregulates cyclin B1 and upregulates p21 expression independent of $p 53 .{ }^{41}$ In addition to manifesting these properties of celecoxib, BPT treatment also increases the level of p53 expression. Western blot studies indicate that repression of cyclin $\mathrm{B} 1$ and $\mathrm{Cdk} 1$ and elevated levels of p21 and p27 is a possible explanation of the $G_{2} / M$ block seen in p53 tumour suppressor-proficient A549 and LS174T cells (Figure 3).

Minor alteration of the microtubule dynamics can arrest the cell cycle progression at mitosis and eventually result in apoptotic cell death. ${ }^{42,43}$ FACS analyses of cells treated with BPT indicate prometaphase block during the cell cycle. The growth of cancer cells in vitro is inhibited by BPT at much lower concentrations than it inhibits the enzyme Cdk4-cyclin D1 in vitro. In addition to these observations, the two- to three-fold 
resistance of BPT to inhibit growth of p53-null Calu-1 cells, in which the mitotic-spindle checkpoint involving tubulin is known to be abnormal, ${ }^{44}$ suggested that BPT may be an antimicrotubule agent. Therefore, the action of BPT on tubulin polymerization in vitro and in live cells was investigated (Figure 4a). BPT was found to inhibit polymerization and enhance depolymerization of tubulin. It is noteworthy to mention that previously discovered tubulin inhibitors are all relatively quite toxic in contrast to what we have discovered. As BPT shows dual mechanism of action at the cellular level, we explored the possibility of its potent cellular activity in reducing in vivo the long-term survival and colony formation efficiency of non-small-cell lung cancer (NSCLC) cells. BPT shows significant reduction in the colony formation efficiency of both p53+ and p53-null cancer cells. In in vivo efficacy studies, BPT showed significant antitumor activity at 1/10th of the MTD in HCT-116 and NCl-H460 xenograft models. In conclusion, a relatively non-toxic compound BPT with dual Cdk4/ tubulin polymerization inhibition activity and promising efficacy in in vivo tumour models has been identified.

\section{Materials and Methods}

Synthesis of BPT (6). Dried round-bottomed flask (RBF) with stirrer bar was charged with biphenyl 2-carboxylic acid $(1 \mathrm{mmol})$ and HBTU $(1.1 \mathrm{mmol})$. Dry DMF $(3 \mathrm{ml})$ was then added dropwise to the RBF. This was followed by the addition of tetrahydro- $\beta$-carboline $(1.1 \mathrm{mmol})$ and diisopropyl ethylamine $(1.1 \mathrm{mmol})$. The reaction mixture was then stirred for $12 \mathrm{~h}$ at room temperature. The reaction was extracted with ethyl acetate and cold water. The organic layer was separated, dried over anhydrous sodium sulphate and solvent was evaporated under reduced pressure. Crude product was purified by silica gel (nos. 100-200) column chromatography using EtOAc:hexane as mobile phase to get 2-(biphenyl-2carbonyl)-2,3,4,9-tetrahydro-1H-pyrido[3,4-b]indole (BPT, 6) in $70 \%$ yield. White powder; yield: HPLC: $t_{R}=10.91 \mathrm{~min}\left(97 \%\right.$ purity); ${ }^{1} \mathrm{H}$ NMR $\left(400 \mathrm{MHz}, \mathrm{CDCl}_{3}\right.$, p.p.m.): $\delta$ (major rotamer) $8.29(1 \mathrm{H}, \mathrm{s}), 7.52-7.02(13 \mathrm{H}, \mathrm{m}), 5.12(1 \mathrm{H}, \mathrm{d}, J=16.0 \mathrm{~Hz})$, $4.41(1 \mathrm{H}, \mathrm{d}, J=20 \mathrm{~Hz}), 3.49-3.43(1 \mathrm{H}, \mathrm{m}), 3.03-2.94(1 \mathrm{H}, \mathrm{m}), 2.62-2.50(1 \mathrm{H}, \mathrm{m})$, 2.17-2.13 $(1 \mathrm{H}, \mathrm{m}) ; \delta$ (distinct peaks for minor rotamer) $7.61(1 \mathrm{H}, \mathrm{s}), 4.20-4.11(1 \mathrm{H}$, m), 4.01-3.97 (1H, m), 3.91-3.87 (1H, m) 3.80-3.74 (1H, m), 2.78-2.74 (1H, m); ${ }^{13} \mathrm{C}$ NMR (100 MHz, DMSO-d, p.p.m.): $\delta$ (major rotamer) 169.02 (CO), 139.47 (C), 138.04 (C), 135.94 (C), 135.58 (C), 130.10 (C), $129.49(\mathrm{CH}), 128.49(\mathrm{CH}), 128.21$ $(\mathrm{CH}), 128.03(\mathrm{CH}), 127.92(\mathrm{CH}), 127.68(\mathrm{CH}), 127.18(\mathrm{CH}), 126.25(\mathrm{C}), 120.78$ $(\mathrm{CH}), 118.46(\mathrm{CH}), 117.43(\mathrm{CH}), 111.0(\mathrm{CH}), 106.35(\mathrm{C}), 44.54\left(\mathrm{CH}_{2}\right), 39.62\left(\mathrm{CH}_{2}\right)$, $20.85\left(\mathrm{CH}_{2}\right) ; \delta$ (distinct peaks for minor rotamer) $169.02(\mathrm{CO}), 139.11(\mathrm{C}), 138.31$ (C), $135.84(\mathrm{C}), 135.64(\mathrm{C}), 130.0(\mathrm{C}), 129.42(\mathrm{CH}), 127.60(\mathrm{CH}), 127.35(\mathrm{CH})$, $126.45(\mathrm{C}), 126.84(\mathrm{CH}), 117.47(\mathrm{CH}), 111.91(\mathrm{CH}), 107.03(\mathrm{C}), 44.40\left(\mathrm{CH}_{2}\right), 39.52$ $\left(\mathrm{CH}_{2}\right), 20.24\left(\mathrm{CH}_{2}\right) ; \mathrm{IR}(\mathrm{KBr}): \nu_{\max } 3396,3275,3057,2959,2924,2850,1720$, 1630, 1612, 1481, 1442, 1426, 1381, 1354, 1306, 1281, 1232, 1160, 1135, 1074, 1040, $1018 \mathrm{~cm}^{-1}$; ESI-MS: m/z $353.10[\mathrm{M}+\mathrm{H}]^{+}$; HR-ESI-MS: m/z 353.1681 calcd for $\mathrm{C}_{24} \mathrm{H}_{21} \mathrm{~N}_{2} \mathrm{O}+\mathrm{H}^{+}$(353.1653).

Kinase assays in vitro. The in vitro kinase assays for testing against Cdk4cyclin D1, Cdk2-cyclin A, Cdk1-cyclin B1 and Cdk9-cyclin T1 were performed inhouse. The methodology and results have been reported previously. ${ }^{20,30-32,45}$ The kinase profiling for 58 representative kinases was carrried out commercially at Millipore Bioscience Division, Livingston, UK.

EtBr displacement assay. The assays were performed in a 96-well plate with clear bottom (Costar, Washington, DC, USA). The assay involved the addition of $10 \mu \mathrm{l}$ of $10 \times$ concentrated stock solution of compounds (dissolved in DMSO and further diluted in $\mathrm{EtBr}$ displacement assay buffer) to $90 \mu \mathrm{l}$ of reaction mixture containing $6 \mu \mathrm{g}$ of purified pBlueScript DNA and $1.3 \mu \mathrm{M} \mathrm{EtBr}$ in EtBr displacement assay buffer with final $\mathrm{pH}$ 7.4. Equivalent amounts of DMSO were added to the vehicle controls. In addition to control samples (DNA+EtBr), test samples (DNA +EtBr+test compounds), blank 1 (EtBr only), blank 2 (DNA only), wells containing DNA and compound were also prepared to test any change in the background fluorescence readings. The reduction in relative fluorescence counts was monitored $\left(\lambda_{\text {excit }}=260 \mathrm{nM} ; \lambda_{\text {emiss }}=600 \mathrm{nM}\right)$ and recorded after 1 min equilibration time. Fascaplysin and actinomycin D, which are known to intercalate d-s DNA, were used as standard compounds in assay. The mean control and test readings were corrected by subtracting blank readings. The percentage fluorescence in the test samples in reaction with control samples was calculated by using following formula:

$\%$ Fluorescence $=\underline{\text { (corrected mean RFU in control }- \text { corrected mean RFU in test }) \times 100}$ corrected mean RFU in control

Topoisomerase I catalysed DNA relaxation or unwinding assay in vitro. For assay, $5 \mathrm{nM}$ supercoiled pBluescript d-s plasmid DNA and $10 \mathrm{U}$ of topoisomerase-I active enzyme were used in each reaction well. To ensure that the assay determines the DNA-intercalating property of compounds and not topoisomerase I inhibition, in a parallel experiment relaxed plasmid DNA was first prepared by treating with topo I enzyme for $30 \mathrm{~min}$ and then used as an initial substrate for the assay. DNA relaxation assays were performed in the presence or absence of compounds in $40 \mu \mathrm{l}$ of DNA unwinding assay buffer. After $30 \mathrm{~min}$ incubation at $37^{\circ} \mathrm{C}$, reaction mixtures were treated with $3 \mu \mathrm{l}$ of $250 \mathrm{mM}$ EDTA and extracted with phenol/chloroform. The DNA was dissolved in tris-EDTA buffer, $\mathrm{pH}$ 8.0. The samples $(20 \mu \mathrm{l})$ were treated with $2 \mu \mathrm{l}$ of $2.5 \%$ SDS, mixed with $2.5 \mu \mathrm{l}$ agarose gel loading buffer (10x) and subjected to electrophoresis on a $0.8 \%$ agarose gel without $\mathrm{EtBr}$ (separating the DNA in the presence of $\mathrm{EtBr}$ would convert the relaxed DNA into the supercoiled form). After the electrophoretic separation, DNA bands were stained with $1 \mu \mathrm{g} / \mathrm{ml} \mathrm{EtBr}$ and visualized using a UV illuminator. The compounds were compared with fascaplysin, which is a known DNAintercalating molecule. Camptothecin, which is a known topoisomerase- I inhibitor, was used to test the activity and inhibition of enzyme.

In vitro cell proliferation assays. All 10 human cancer cell lines were maintained at $37^{\circ} \mathrm{C}$ in $5 \% \mathrm{CO}_{2}$ in RPMI- 1640 medium, supplemented with $10 \%$ foetal calf serum and $100 \mu \mathrm{g} / \mathrm{ml}$ normocin. The 10 cancer cell lines used for screening were all obtained from ATCC (Manassas, VA, USA); they were the NSCLC (a form of cancer that is resistant to chemotherapy) lines: $\mathrm{NCl}-\mathrm{H} 460\left(\mathrm{pRb}^{+}\right.$,

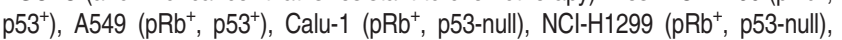
$\mathrm{NCl}-\mathrm{H} 358$ (pRb-null, p53-null); the colon cancer line LS174T $\left(\mathrm{pRb}^{+}, \mathrm{p53} 3^{+}\right)$; the prostate cancer line PC-3 (pRb+, p53-null); the pancreatic cancer line MiaPaca ( $\mathrm{pRb}^{+}, \mathrm{p53}$-mutant). The genotypes within brackets indicate the status of the tumour suppressor proteins $\mathrm{pRb}$ and $\mathrm{p53}$. The mouse embryonic normal hepatic cell line (BNL CL2) and its SV40 large T-antigen-transformed counterpart cell line (BNL SV A.8) were also purchased from ATCC. The large T-antigen inactivates the tumour suppressor proteins $\mathrm{p} 53$ and $\mathrm{pRb}$. The detailed procedure of cell proliferation (MTT) assay and $\mathrm{IC}_{50}$ determination was described previously. ${ }^{32}$

Flow cytometric analysis. The untreated (control) and treated (with test compounds) cells were harvested by trypsinization, washed once with PBS and then fixed in $70 \%$ chilled $\left(-20^{\circ} \mathrm{C}\right)$ ethanol for minimum $1 \mathrm{~h}$. After the fixation step, cells were centrifuged for $5 \mathrm{~min}$ at $3000 \times g$ at room temperature, and the pellet was suspended in PBS containing $50 \mu \mathrm{g} / \mathrm{ml}$ propidium iodide (Sigma-Aldrich, Dorset, UK; cat. no. P-4170) and $0.5 \mathrm{mg} / \mathrm{ml}$ DNase-free ribonuclease (Sigma-Aldrich; cat. no. R-5503). The cells were stained for $1 \mathrm{~h}$ in the dark at $4{ }^{\circ} \mathrm{C}$. Cell cycle analysis was performed on the Beckman Coulter (Epics Altra) fluorescenceactivated cell sorter (Beckman Coulter UK Ltd, Buckinghamshire, UK). To gate all the events that represent single cells, and not cell doublets or cell clumps, the following analyses were performed on the samples. Cytograms of propidium iodide fluorescence peak signal versus integrated fluorescence or the linear signal were plotted. All data points on the straight line were isolated in a single gate and the gated data was further used for plotting a histogram that represents a complete cell cycle. The total number of events was not allowed to exceed 200 events per s. Data acquisition was stopped after a minimum of 10000 events had been collected.

Western blotting. A549, LS174T and MiaPaCa cells were seeded in $25 \mathrm{~cm}^{2}$ tissue culture flasks in the complete growth medium. When the culture flasks reached $40-50 \%$ confluency, cells were treated with BPT (IC ${ }_{50}$ concentration) for $24 \mathrm{~h}$. Cells were harvested by trypsinization, washed in ice-cold PBS and then lysed in buffer (Sigma-Aldrich; cat. no. C-2978) containing protease inhibitor cocktail (Sigma-Aldrich; cat. no. P8340). The lysates were centrifuged at 14000 r.p.m. (revolutions per minute) for $10 \mathrm{~min}$ at $4{ }^{\circ} \mathrm{C}$ and the total protein concentrations were estimated in the clear supernatants using the Bradford method. Equal amounts of 
protein $(40 \mu \mathrm{g})$ were loaded and electrophoresed on $10 \%$ SDS-polyacrylamide gels and blotted on Immobilon-P Transfer Membrane (Millipore; cat. no.IPVH20200). The blots were probed with respective primary antibodies (at $4^{\circ} \mathrm{C}$, overnight) at the following dilutions: cdc2 (New England Biolabs, Hitchin, UK; cat. no. 9110) at 1:1000 to detect Cdk1; cyclin B1 (CRUK, London, UK; cat. no. V152) at 1:1500 dilution to detect cyclin B1; Pab 1801 (Santa Cruz Biotechnology, Heidelberg, Germany; cat. no. sc-98) at 1:500 dilution to detect p53; N-20 (Santa Cruz Biotechnology; cat. no. sc-469) at 1:500 dilution to detect p21; C-19 (Santa Cruz Biotechnology; cat. no. sc-528) at $1: 250$ dilution to detect p27; AC-40 (SigmaAldrich; cat. no. A4700) at 1:2000 dilution to detect actin. Appropriate secondary antibodies conjugated with horseradish peroxidase were used and the protein bands were visualized by chemiluminescence using the ECL Kit (Santa Cruz Biotechnology; cat. no. sc-2048).

Western blotting to test effect of BPT on tubulin polymerization and depolymerization of stabilized tubulin in cells. A549 (NSCLC) cells were seeded at a concentration of 10000 cells per well in $1 \mathrm{ml}$ complete growth medium in 24-well per $15 \mathrm{~mm}$ culture plates. The plates were incubated for $24 \mathrm{~h}$ for cell attachment and stabilization. In the first set of experiments, the cells were treated with $10 \mathrm{nM}$ paclitaxel and different concentrations of BPT for $30 \mathrm{~min}$ (cells underwent simultaneous treatment of paclitaxel and BPT). In the second set of experiments, to study the effect of BPT on the stabilised form of tubulin, cells were pretreated with $10 \mathrm{nM}$ paclitaxel for $30 \mathrm{~min}$. The cell monolayer was washed two times with sterile PBS and fresh growth medium containing different concentrations of BPT were added. The plates were further incubated for $30 \mathrm{~min}$, the cell monolayers were washed two times with sterile PBS at room temperature and then $100 \mu$ tubulin extraction buffer $(1 \mathrm{mM} \mathrm{MgCl}, 2 \mathrm{mM}$ EGTA, $0.5 \% \mathrm{NP} 40$ and $20 \mathrm{mM}$ Tris- $\mathrm{HCl}(\mathrm{pH} 6.8))$ supplemented with $2 \mathrm{mM}$ phenylmethylsulfonyl fluoride, and a protease inhibitor cocktail (Sigma-Aldrich; cat. no. P8340) was added per well. After a short and vigorous vortex mixing, the cell lysates were incubated at room temperature for $5 \mathrm{~min}$ and then centrifuged at 16000 r.p.m. for $10 \mathrm{~min}$ to separate the soluble and polymerized tubulin fractions. Each supernatant and pellet fraction was mixed with $10 \times$ sample buffer, heated for $7 \mathrm{~min}$ at $95^{\circ} \mathrm{C}$ and resolved on $10 \%$ SDS-polyacrylamide gels. The resolved proteins were then subjected to western blotting (as described above) with a specific $\alpha$-tubulin antibody B-7 (Santa Cruz Biotechnology; cat. no. sc-5286).

Cell-free tubulin polymerization assay in vitro. The purified tubulin was obtained commercially (Cytoskeleton Inc., Denver, CO, USA) and the polymerization assays were carried out according to the method described previously. ${ }^{36}$ Tubulin polymerization assay is based on the adaptation of the original methods of Lee and Timasheff, ${ }^{46}$ who demonstrated that light is scattered by microtubules to an extent that is proportional to the concentration of the microtubule polymer. The resulting polymerization curves are representative of the three phases of microtubule polymerization, namely nucleation, growth and steady-state equilibrium. Paclitaxel and nocodazole were used in the assay as a known enhancer and inhibitor of tubulin polymerization, respectively. The ability of BPT to inhibit tubulin polymerization in vitro was determined according to the manufacturer's instructions. Briefly, tubulin protein $(3 \mathrm{mg} / \mathrm{ml})$ was polymerized in GTP buffer ( $80 \mathrm{mM}$ PIPES, pH 6.9, $2 \mathrm{mM} \mathrm{MgCl}_{2}, 0.5 \mathrm{mM} \mathrm{EGTA}, 10.2 \%$ glycerol and $1 \mathrm{mM}$ GTP) in the presence of a range of BPT concentrations at $37^{\circ} \mathrm{C}$ in a temperature-regulated Biotech spectrophotometer (Potton, Bedfordshire, UK). The absorbance (at $340 \mathrm{~nm}$ ) kinetics of 61 cycles for each sample was studied and the readings were recorded at an interval of $1 \mathrm{~min}$.

Colony formation assay. A549 and Calu-1 cells were plated at a concentration of 500 cells per well in $35 \mathrm{~mm} / 6$-well plates in $2 \mathrm{ml}$ complete medium. The plates were incubated for $24 \mathrm{~h}$ stabilization and further incubated with a range of concentrations of fascaplysin and BPT for $24 \mathrm{~h}$. Plates were then gently washed with PBS, replaced with fresh medium and incubated at $37^{\circ} \mathrm{C}$. After $10-$ 12 days, cells were fixed in methanol:acetic acid (2:1) fixative for $10 \mathrm{~min}$, washed, air dried and stained with $1 \%$ crystal violet. The colonies were evaluated by visual counts. The number of colonies in treated cultures was expressed as a percentage of the control cultures. All results represent means and standard deviations from at least three independent experiments.

Detection of apoptosis by nuclei staining with fluorescence dye DAPI. Mouse embryonic normal hepatic cell line (BNL CL2) and its SV40-mediated transformed cell line (BNL SV A.8) were used to study the levels of apoptosis. Apoptosis and nuclear fragmentation was detected using DAPI staining followed by observations under fluorescence microscope. ${ }^{47}$ Cells were seeded at a concentration of 50000 cells per well in $35 \mathrm{~mm} / 6$-well plates in total of $2 \mathrm{ml}$ complete growth medium. After $24 \mathrm{~h}$ stabilization period, cells were further incubated in the presence of $I C_{50}$ concentration of BPT for $48 \mathrm{~h}$. Followed by the drug exposure, the cells (along with the floating cells) were collected by trypsinization, washed in sterile PBS and fixed in ethanol:acetic acid (3:1) fixative for $10 \mathrm{~min}$. The cell suspension was dropped on a glass slide to break open the cells and allowed to air dry. The smear formed on the slide was mounted in a medium containing $1 \mu \mathrm{g} / \mathrm{ml}$ DAPI and covered with coverslip. The slides were observed under fluorescence microscope and minimum 500 nuclei were counted for each sample.

Pharmacokinetic analysis. Oral and intravenous pharmacokinetic studies of BPT were carried out in BALB/c male mice of age 4-6 weeks, by administering BPT orally and intravenous formulation at dose of $10 \mathrm{mg} / \mathrm{kg}$ for oral and $1 \mathrm{mg} / \mathrm{kg}$ for intravenous. Plasma samples were collected at appropriate time points between the range 0 and $24 \mathrm{~h}$, and analysed by LC-MS-MS. Mean plasma concentration calculated and data were further analysed to determine PK parameters such as $t_{1 / 2}, C_{\max }, A C U, V_{d}$ and $C L$, using WinNonlin 5.3 software package (Pharsight Company, Princeton, NJ, USA).

MTD finding studies for in vivo experiments. Swiss-albino mice were used to determine the MTD for the compound. BPT was weighed and mixed with $0.5 \%$ (w/v) carboxymethylcellulose and triturated with Tween-20 (secundum artum) with gradual addition of water to make up the final concentration. Care was taken not to exceed $>0.25 \%$ of Tween-20 in the final formulation of the BPT. In this study, six animals per group were administered with BPT at different doses for 5 days $(Q 1 D \times 5)$ via intraperitoneal route. Animals were monitored for weight loss, morbidity symptoms and mortality up to 2 weeks by the end of treatment. Significant weight loss was considered when mean animal weight dropped by $\geqslant 10 \%$ and was considered highly significant when the drop was $\geqslant 20 \%$.

\section{Efficacy study in SCID mice}

HCT-116 experiments: A group of 60 SCID (SCID strain-CBySmn.CB17Prkdc ${ }^{\text {scid } / J ; ~ T h e ~ J a c k s o n ~ L a b o r a t o r y, ~ B a r ~ h a r b o r, ~ M E, ~ U S A ; ~ S t o c k ~ n o . ~ 001803) ~ m a l e ~}$ mice weighing 18-25 $\mathrm{g}$ and 6-8 weeks old were used for the studies. Human colon carcinoma, HCT-116 (ATCC; cat. no. CCL-247) cells were grown in McCoy's 5A medium supplemented with 10\% FBS (Sigma-Aldrich). The cultured cells were injected subcutaneously into the dorsal side of SCID mice at the dose of $6.6 \times 10^{6}$ cells in $0.2 \mathrm{ml}$ of suspension. When the tumour growth reached to about $4-6 \mathrm{~mm}$ in diameter (over about 5 days), the animals were randomly divided into eight groups, each containing seven mice. The treatments were continued for 9 consecutive days intraperitoneally. Flavopiridol $(2.5 \mathrm{mpk})$ was used as a positive control in this study.

$\mathrm{NCl}-\mathrm{H} 460$ experiments: A group of 65 SCID (SCID strain-CBySmn.CB17Prkdc scid/J; The Jackson Laboratory; Stock no. 001803) female mice weighing 15-24 $\mathrm{g}$ and 6-8 weeks old were used. Human non-small-cell lung carcinoma, $\mathrm{NCl}$ H460 (ATCC; cat. no. HTB-177) cells grown in RPMl-1640 medium supplemented with 10\% FBS (Sigma-Aldrich). The cultured cells were injected subcutaneously into the dorsal side of SCID mice at a tune of $5.3 \times 10^{6}$ cells in $0.2 \mathrm{ml}$ of suspension. When the tumour growth reached about 4-6 $\mathrm{mm}$ in diameter (about 6 days), the animals were randomly divided into eight groups, each containing 6 or 7 mice. The treatments were continued for 9 consecutive days intraperitoneally. Flavopiridol (2.5 mpk) was used as a positive control in this study.

Tumour weight measurements: Tumour size was recorded at 2-5 day intervals. Tumour weight $(\mathrm{mg})$ was estimated according to the formula for a prolate ellipsoid: (length $(\mathrm{mm}) \times$ width $\left.\left.(\mathrm{mm})^{2}\right) \times 0.5\right)$ assuming specific gravity to be one and $\pi$ to be 3 . Tumour growth in compound treated animals is calculated as T/C (treated/ control) $\times 100 \%$ and growth inhibition percent (\% GI) was $(100-\% \mathrm{~T} / \mathrm{C}){ }^{48-50}$

Body weight measurements: The body weights of animals in different treatment and control groups were monitored by taking the measurements daily during the treatment schedule. By considering the body weight at the start of the treatment as $100 \%$, the percent weight loss was calculated on subsequent days of treatments.

Statistical analysis: Data from each experiment was analysed by Microsoft Excel 2000. Statistically significant differences were identified and analysed using Student's $t$-test for multiple comparisons versus control group. ${ }^{48-50}$ The experiments were performed by Piramal Life Sciences (Mumbai, India), on a service contract. 
Molecular docking and molecular dynamic simulations. The available crystal structures of Cdk4/cyclin D1 are in the apo form and have several missing residues, and thus they cannot be used for molecular modelling. ${ }^{33}$ In the present study, we have used a hybrid homology model of Cdk4/cyclin D1 described by Shafiq et al., ${ }^{51}$ which was developed from the Cdk4/cyclin D apocrystal structure (PDB: 2W96) by incorporating positions of missing gaps and activation loops from Cdk2/cyclin A (PDB: 1 FIN). ${ }^{52}$ This hybrid homology model was subjected to protein preparation wizard for $\mathrm{H}$-bond optimization, heterogeneous state generation, protonation and overall minimization. Grid file of docking was constructed using $\mathrm{XYZ}$ coordinates of the $\mathrm{N}$ atom of Val96 residue with a binding site of $12 \AA$ radius grid box $(X=-10.521, Y=208.683, Z=107.944)$. For Cdk2 docking, the Cdk2 apoprotein (PDB ID: 1FIN) was subjected to protein preparation wizard for filling missing loops and side chains (using prime), ionization, $\mathrm{H}$-bond optimization, heterogeneous state generation, protonation and overall minimization. Grid file of docking was constructed using XYZ coordinates of the N atom of Leu83 residue with a binding site of $12 \AA$ radius grid box $(X=-10.406, Y=209.105$, $Z=107.576)$.

For tubulin docking, the tubulin-colchicine complex (PDB ID: 1SA0) was retrieved from the protein data bank. ${ }^{53}$ In this complex, protein is heterodimeric in nature, consisting of two $\alpha$-chains (451 residues), two $\beta$-chains (452 residues) and the Stathmin-like domain (142 residues). Crystal structure was subjected to protein preparation wizard for filling missing loops and side chains (using prime), ionization, $\mathrm{H}$-bond optimization, heterogeneous state generation, protonation and overall minimization. All other ligands, water and ions were removed except colchicine. Grid file for docking was constructed considering colchicine ligand as centroid of grid box of $10 \AA$ size at interphase of $\alpha / \beta$ tubulin ( $C$ and D chains). All ligands were sketched in Maestro, prepared using ligprep and docked by Glide molecular docking software (Schrodinger LLC, Bangalore, India) in XP mode.

The Cdk4-BPT docked complex obtained from XP docking was subjected to system builder, in which TIP4P-Ew was used as an aqueous solvent model. The cubic box of $12 \AA$ radius was used to define the core and overall complex was neutralized by adding one $\mathrm{Cl}^{-}$counter ion for simulation. Further this complex was minimized by steepest descent method followed by the Broyden-Fletcher-Goldfarb-Shanno algorithm with convergence threshold of $2.0 \mathrm{kcal} / \mathrm{mol}$ and overall 1000 iterations. MD simulations were carried out at normal temperature and pressure $\left(300^{\circ} \mathrm{K}\right.$ and $1.01325 \mathrm{bar}$, respectively). Thermostat and barostat method opted was langevin with ensemble pathway comprising NVT (constant number of particles, volume and temperature) and isotropic coupling method. Overall model system was relaxed before $10 \mathrm{~ns}$ simulation and coulombic interactions were defined by short-range cutoff radius of $9.0 \AA$ and by long-range smooth particle mesh Ewald tolerance to $1 e-09$.

\section{Conflict of Interest}

The authors declare no conflict of interest.

Acknowledgements. The research work in the author's laboratory was funded by Cancer Research UK (C8860/A3284 to BC and PRJ). SBB is thankful to SERBDST (Grant No. SR/FT/CS-168/2011, fast-track grant for young scientists) for financial support.

\section{Author contributions}

SM (DMU) performed all Cdk assays and in vitro biology experiments; PRJ designed fascaplysin analogues for chemical syntheses; BC designed all in vitro biology experiments and in vivo studies; SM (IIIM) synthesized BPT for pharmacokinetic studies; PJ carried out molecular modelling studies; PJ and SBB interpreted modelling results; SBB, RAV and BC contributed to manuscript writing.

1. Giacinti C, Giordano A. RB and cell cycle progression. Oncogene 2006; 25 : 5220-5227.

2. Yamasaki L. Role of the RB tumor suppressor in cancer. Cancer Treat Res 2003; 115 209-239.

3. Ortega S, Malumbres M, Barbacid M. Cyclin D-dependent kinases, INK4 inhibitors and cancer. Biochim Biophys Acta 2002; 1602: 73-87.

4. Sheppard KE, McArthur GA. The cell-cycle regulator CDK4: an emerging therapeutic target in melanoma. Clin Cancer Res 2013; 19: 5320-5328.

5. Soni R, O'Reilly T, Furet P, Muller L, Stephan C, Zumstein-Mecker S et al. Selective in vivo and in vitro effects of a small molecule inhibitor of cyclin-dependent kinase 4. J Natl Cancer Inst 2001; 93: 436-446.

6. Lambert AP, Anschau F, Schmitt VM. p16INK4A expression in cervical premalignant and malignant lesions. Exp Mol Pathol 2006; 80: 192-196.
7. Roussel MF. The INK4 family of cell cycle inhibitors in cancer. Oncogene 1999; 18: 5311-5317.

8. Sun Y, Luo D, Liao DJ. CyclinD1 protein plays different roles in modulating chemoresponses in MCF7 and MDA-MB231 cells. J Carcinogen 2012; 11: 12

9. Fu M, Wang C, Li Z, Sakamaki T, Pestell RG. Minireview: Cyclin D1: normal and abnormal functions. Endocrinology 2004; 145: 5439-5447.

10. Ikeda Y, Oda K, Kawana K, Aoki D, Osuga Y, Fujii T. Cyclin-dependent kinase 4/6-specific activities as a biomarker for prognosis and chemosensitivity in endometrial cancer. Obstet Gynecol 2014; 123: $92 \mathrm{~S}$

11. Landis MW, Pawlyk BS, Li T, Sicinski P, Hinds PW. Cyclin D1-dependent kinase activity in murine development and mammary tumorigenesis. Cancer Cell 2006; 9: 13-22.

12. Malumbres M, Barbacid M. Is Cyclin D1-CDK4 kinase a bonafide cancer target? Cancer Cell 2006; 9: 2-4.

13. Yu $Q$, Sicinska E, Geng $Y$, Ahnstrom M, Zagozdzon A, Kong $Y$ et al. Requirement for CDK4 kinase function in breast cancer. Cancer Cell 2006; 9: 23-32.

14. Liu N, Fang H, Li Y, Xu W. Recent research in selective cyclin-dependent kinase 4 inhibitors for anti-cancer treatment. Curr Med Chem 2009; 16: 4869-4888.

15. Tsou H-R, Otteng M, Tran T, Floyd MB, Reich M, Birnberg $G$ et al. 4-(Phenylaminomethylene)isoquinoline-1,3(2H,4H)-diones as potent and selective inhibitors of the cyclin-dependent kinase 4 (CDK4). J Med Chem 2008; 51: 3507-3525.

16. Cho YS, Angove H, Brain C, Chen $\mathrm{CH}-\mathrm{T}$, Cheng H, Cheng R et al. Fragment-based discovery of 7-azabenzimidazoles as potent, highly selective, and orally active CDK4/6 inhibitors. ACS Med Chem Lett 2012; 3: 445-449.

17. Tsou H-R, Liu X, Birnberg G, Kaplan J, Otteng M, Tran $T$ et al. Discovery of 4-(benzylaminomethylene)isoquinoline-1,3-(2H,4H)-diones and 4-[(pyridylmethyl) aminomethylene]isoquinoline-1,3-(2H,4H)-diones as potent and selective inhibitors of the cyclin-dependent kinase 4. J Med Chem 2009; 52: 2289-2310.

18. Mascarenhas NM, Ghoshal N. Combined ligand and structure based approaches for narrowing on the essential physicochemical characteristics for CDK4 inhibition. J Chem Inf Model 2008; 48: 1325-1336

19. Honma T, Hayashi K, Aoyama T, Hashimoto N, Machida T, Fukasawa K et al. Structurebased generation of a new class of potent Cdk4 inhibitors: New de novo design strategy and library design. J Med Chem 2001; 44: 4615-4627.

20. Aubry C, Jenkins PR, Mahale S, Chaudhuri B, Marechal JD, Sutcliffe MJ. New fascaplysinbased CDK4-specific inhibitors: design, synthesis and biological activity. Chem Commun 2004; 15: 1696-1697.

21. Dickson MA, Tap WD, Keohan ML, D'Angelo SP, Gounder MM, Antonescu CR et al. Phase II trial of the CDK4 inhibitor PD0332991 in patients with advanced CDK4-amplified welldifferentiated or dedifferentiated liposarcoma. J Clin Oncol 2013; 31: 2024-2028.

22. Mor M, Spadoni G, Diamantini G, Bedini A, Tarzia G, Silva C et al. Antioxidant and cytoprotective activity of indole derivatives related to melatonin. Adv Exp Med Biol 2003; 527: 567-575.

23. Andreadou I, Tasouli A, Bofilis E, Chrysselis M, Rekka E, Tsantili-Kakoulidou A et al. Antioxidant activity of novel indole derivatives and protection of the myocardial damage in rabbits. Chem Pharm Bull 2002; 50: 165-168.

24. Gelbert LM, Cai S, Lin X, Sanchez-Martinez C, Del Prado M, Lallena MJ et al. Preclinical characterization of the CDK4/6 inhibitor LY2835219: in vivo cell cycle-dependent/ independent anti-tumor activities alone/in combination with gemcitabine. Invest New Drugs 2014; 32: 825-837.

25. Joshi KS, Padgaonkar A, Rathos M, Wagh V, Manohar S, Bhatia D et al. Abstract 3054: P1446A-05: a new oral cyclin-dependent kinase inhibitor with potent preclinical antitumor activity (Proceedings: AACR 103rd Annual Meeting 2012). Cancer Res 2012; 72: 3054

26. Beattie JF, Breault GA, Ellston RP, Green S, Jewsbury PJ, Midgley CJ et al. Cyclindependent kinase 4 inhibitors as a treatment for cancer. Part 1: identification and optimisation of substituted 4,6-bis anilino pyrimidines. Bioorg Med Chem Lett 2003; 13: 2955-2960.

27. Segraves NL, Robinson SJ, Garcia D, Said SA, Fu X, Schmitz FJ et al. Comparison of fascaplysin and related alkaloids: a study of structures, cytotoxicities, and sources. I Nat Prod 2004; 67: 783-792.

28. Hormann A, Chaudhuri B, Fretz H. DNA binding properties of the marine sponge pigment fascaplysin. Bioorg Med Chem 2001; 9: 917-921.

29. Mahale S, Bharate SB, Manda S, Joshi P, Bharate SS, Jenkins PR et al. Biphenyl-4carboxylic acid [2-(1H-indol-3-yl)-ethyl]-methylamide (CA224), a non-planar analog of fascaplysin inhibits Cdk4 and tubulin polymerization: evaluation of in vitro and in vivo anticancer activity. J Med Chem 2014; 57: 9658-9672.

30. Aubry C, Wilson AJ, Jenkins PR, Mahale S, Chaudhuri B, Marechal JD et al. Design, synthesis and biological activity of new CDK4-specific inhibitors, based on fascaplysin. Org Biomol Chem 2006; 4: 787-801.

31. Mahale S, Aubry C, James Wilson A, Jenkins PR, Marechal JD, Sutcliffe MJ et al. CA224, a non-planar analogue of fascaplysin, inhibits Cdk4 but not Cdk2 and arrests cells at G0/G1 inhibiting pRB phosphorylation. Bioorg Med Chem Lett 2006; 16: 4272-4278.

32. Mahale S, Aubry C, Jenkins PR, Marechal JD, Sutcliffe MJ, Chaudhuri B. Inhibition of cancer cell growth by cyclin dependent kinase 4 inhibitors synthesized based on the structure of fascaplysin. Bioorg Chem 2006; 34: 287-297.

33. Day PJ, Cleasby A, Tickle IJ, O'Reilly M, Coyle JE, Holding FP, et al. Crystal structure of human CDK4 in complex with a D-type cyclin. Proc Natl Acad Sci USA 2009; 106: 4166-4170. 
34. Yonekura N, Mutoh M, Miyagi YET. Ethidium bromide binding sites in DNA gel. Chem Lett 2000; 8: 954-958.

35. Fiorini C, Cordani M, Padroni C, Blandino G, Di Agostino S, Donadelli M. Mutant p53 stimulates chemoresistance of pancreatic adenocarcinoma cells to gemcitabine. Biochim Biophys Acta 2015; 1853: 89-100.

36. Augustin E, Wheatley DN, Lamb J, Konopa J. Imidazoacridinones arrest cell-cycle progression in the G2 phase of L1210 cells. Cancer Chemother Pharmacol 1996; 38: 39-44.

37. Agarwal ML, Agarwal A, Taylor WR, Stark GR. p53 controls both the G2/M and the G1 cell cycle checkpoints and mediates reversible growth arrest in human fibroblasts. Proc Nat Acad Sci USA 1995; 92: 8493-8497.

38. Blagosklonny MV. Cell senescence and hypermitogenic arrest. EMBO Rep 2003; 4 358-362.

39. Chen YN, Sharma SK, Ramsey TM, Jiang L, Martin MS, Baker K et al. Selective killing of transformed cells by cyclin/cyclin-dependent kinase 2 antagonists. Proc Natl Acad Sci USA 1999; 96: 4325-4329.

40. Parker BW, Kaur G, Nieves-Neira W, Taimi M, Kohlhagen G, Shimizu T et al. Early induction of apoptosis in hematopoietic cell lines after exposure to flavopiridol. Blood 1998; 91 : 458-465.

41. Dvory-Sobol H, Cohen-Noyman E, Kazanov D, Figer A, Birkenfeld S, Madar-Shapiro L et al. Celecoxib leads to $\mathrm{G} 2 / \mathrm{M}$ arrest by induction of p21 and down-regulation of cyclin B1 expression in a p53-independent manner. Eur J Cancer 2006; 42: 422-446.

42. Bhalla KN. Microtubule-targeted anticancer agents and apoptosis. Oncogene 2003; 22 9075-9086.

43. Zhou J, Giannakakou P. Targeting microtubules for cancer chemotherapy. Curr Med Chem Anticancer Agents 2005; 5: 65-71.

44. Masuda A, Maeno K, Nakagawa T, Saito H, Takahashi T. Association between mitotic spindle checkpoint impairment and susceptibility to the induction of apoptosis by antimicrotubule agents in human lung cancers. Am J Pathol 2003; 163: 1109-1116.

45. Aubry C, Patel A, Mahale S, Chaudhuri B, Maréchal J-D, Sutcliffe MJ et al. The design and synthesis of novel 3-[2-indol-1-yl-ethyl]-1H-indole derivatives as selective inhibitors of CDK4 Tetrahedron Lett 2005; 46: 1423-1425.

46. Lee JC, Timasheff SN. In vitro reconstitution of calf brain microtubules: effects of solution variables. Biochemistry 1977; 16: 1754-1764.
47. Sandra F, Hendarmin L, Nakao Y, Nakamura N, Nakamura S. Inhibition of Akt and MAPK pathways elevated potential of TNFalpha in inducing apoptosis in ameloblastoma. Oral Oncol 2006; 42: 39-45.

48. Mohammad RM, Dugan MC, Mohamed AN, Almatchy VP, Flake TM, Dergham ST et al. Establishment of a human pancreatic tumor xenograft model: potential application for preclinical evaluation of novel therapeutic agents. Pancreas 1998; 16: 19-25.

49. Mohammad RM, Mohamed AN, Hamdan MY, Vo T, Chen B, Katato K et al. Establishment of a human B-CLL xenograft model: utility as a preclinical therapeutic model. Leukemia 1996; 10: $130-137$.

50. Tashiro T, Inaba M, Kobayashi T, Sakurai Y, Maruo K, Ohnishi Y et al. Responsiveness of human lung cancer/nude mouse to antitumor agents in a model using clinically equivalent doses. Cancer Chemother Pharmacol 1989; 24: 187-192.

51. Shafiq MI, Steinbrecher T, Schmid R. Fascaplysin as a specific inhibitor for CDK4: insights from molecular modelling. PLOS One 2012; 7: e42612.

52. Jeffrey PD, Russo AA, Polyak K, Gibbs E, Hurwitz J, Massague J et al. Mechanism of CDK activation revealed by the structure of a cyclinA-CDK2 complex. Nature 1995; 376: 313-320.

53. Ravelli RB, Gigant B, Curmi PA, Jourdain I, Lachkar S, Sobel A et al. Insight into tubulin regulation from a complex with colchicine and a stathmin-like domain. Nature 2004; 428 : 198-202.

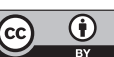

Cell Death and Disease is an open-access journal published by Nature Publishing Group. This work is licensed under a Creative Commons Attribution 4.0 International License. The images or other third party material in this article are included in the article's Creative Commons license, unless indicated otherwise in the credit line; if the material is not included under the Creative Commons license, users will need to obtain permission from the license holder to reproduce the material. To view a copy of this license, visit http://creativecommons.org/licenses/by/4.0/

Supplementary Information accompanies this paper on Cell Death and Disease website (http://www.nature.com/cddis) 